\title{
HVMANITAS
}

\section{O discurso acerca de los versos de Faria y Sousa no prólogo do comentário das Rimas Várias de Camões}

\author{
Autor(es): $\quad$ Vitali, Marimilda \\ Publicado por: $\begin{aligned} & \text { Faculdade de Letras da Universidade de Coimbra, Instituto de Estudos } \\ & \text { Clássicos }\end{aligned}$ \\ URL \\ persistente: \\ URI:http://hdl.handle.net/10316.2/8516 \\ DOI: $\quad$ DOI:http://dx.doi.org/10.14195/2183-1718_62_11
}

Accessed : $\quad$ 26-Apr-2023 16:16:32

A navegação consulta e descarregamento dos títulos inseridos nas Bibliotecas Digitais UC Digitalis, UC Pombalina e UC Impactum, pressupõem a aceitação plena e sem reservas dos Termos e Condições de Uso destas Bibliotecas Digitais, disponíveis em https://digitalis.uc.pt/pt-pt/termos.

Conforme exposto nos referidos Termos e Condições de Uso, o descarregamento de títulos de acesso restrito requer uma licença válida de autorização devendo o utilizador aceder ao(s) documento(s) a partir de um endereço de IP da instituição detentora da supramencionada licença.

Ao utilizador é apenas permitido o descarregamento para uso pessoal, pelo que o emprego do(s) título(s) descarregado(s) para outro fim, designadamente comercial, carece de autorização do respetivo autor ou editor da obra.

Na medida em que todas as obras da UC Digitalis se encontram protegidas pelo Código do Direito de Autor e Direitos Conexos e demais legislação aplicável, toda a cópia, parcial ou total, deste documento, nos casos em que é legalmente admitida, deverá conter ou fazer-se acompanhar por este aviso.

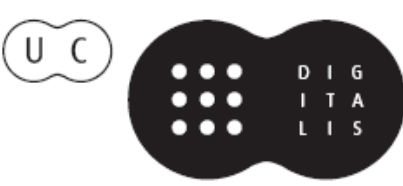


humanitas

Vol. LXII

2010 


\title{
O DISCURSO ACERCA DE LOS VERSOS DE FARIA Y SOUSA. NO PRÓLOGO DO COMENTÁRIO DAS RIMAS VARIAS DE CAMÕES
}

\author{
MARIMilda Vitali \\ Universidade de Coimbra
}

\section{Resumo}

Segundo o cronista catalano Antonio Beuter, o inventor do decassílabo não foi um poeta da escola siciliana, mas sim Jordi de Sant Jordi. A esta mistificação, que se tornara bastante popular, Faria e Sousa substituiu outra, forjada pelo cronista Bernardo de Brito: já cerca de 1090 Gonçalo Hermigues, o 'traga-Mouros', teria composto alguns poemas em decassílabos, dedicados à sua amada Oureana. $\mathrm{Na}$ verdade, a 'canção de Hemigues' faz parte de um corpus de cinco poemas pretensamente antigos, compostos sob o reino de Felipe II no intuito de enobrecer as orígens de Portugal. Traduzida por Almeida Garrett, a lenda de Hermigues foi logo objecto de uma longa controversia entre Teófilo Braga e Carolina Michaëlis.

Palavras-chave: Faria e Sousa Rimas várias - origens do decassílabo Gonçalo Hermigues.

\begin{abstract}
Was the decasyllable really invented by a poet of the Sicilian school? According to the Catalan chronicler Antonio Beuter, it is Jordi de Sant Jordi who should rather be credited with the invention of this verse. For Beuter's plain mystification, which nevertheless had become increasingly popular, Faria e Sousa managed to substitute a literary forgery found in Bernardo de Brito's Chrónica de Cister. According to Brito's version, Gonçalo Hermigues, the legendary hero styled 'Traga-Mouros', would have written around 1090 some decasyllabic lines dedicated to his beloved Oureana. In fact, that is one of the five apocryphal poems composed during Philip II's reign with a view to dignifying the origins of Portugal. After Garrett's poetic translation, that legend became the subject of a polemic exchange between Teófilo Braga and Carolina Michaëlis.

Key-words: Faria e Sousa Rimas várias - origins of decassílabo - Gonçalo Hermigues.
\end{abstract}


1. O presente artigo concerne ao Discurso desenvolvido por Faria y Sousa em guisa de prólogo ao seu comentário das Rimas camonianas. ${ }^{1} \mathrm{~A}$ questão principal ali encarada diz respeito aos versos decassílabos, «de que vulgarmente se piensa fue Garcilasso su primer Introdutor en España, imitando a Italia». Neste contexto, Faria y Sousa defende que a prioridade pertence a Boscán, conforme aquilo que este afirma «en su Prólogo a la entrada del libro 2 . que consta desta suerte de versos $(. ..){ }^{2}$ Y adelante dice que lo hizo a instância de Navagero Poeta conocido en Italia». ${ }^{3}$ Faria y Sousa apoia-se na autoridade de Fernando de Herrera: «en la introdución a las Notas sobre Garcilasso», este confirma que depois do Marquês de Santillana, «devieron ser los primeros Juan Boscán, Don Diego de Mendoça, y casi iguales suyos en el tiempo Gutierre de Citina, y Garcilasso». ${ }^{4}$ Veja-se a seguir a conclusão de Faria y Sousa:

Lo en que yo reparo es en dezir Boscán que siguió el parecer de Garcilasso en esta invención, por ser tenido en el mundo por regla cierta en esto (...). ${ }^{5}$ Esto es que Garcilasso antes de escrivir era famoso estudiante en los Poetas, y después vino a escrivir famosamente; y por esto, sin aver escrito, podía tener fama de docto en esta ciencia, y dar consejo a Boscán. ${ }^{6}$

1 Discurso acerca de los Versos de que constan los Poemas contenidos en los tres Tomos primeros de estas Rimas (...); y de la perfeción de los Sonetos, y quales Autores se aventajaron en ella, in Rimas várias de Luis de Camões comentadas por M. de Faria y Sousa. Nota introdutória do Prof. F. Rebelo Gonçalves. Prefácio do Prof. J. de Sena, Primeira Parte: Tomos I e II, Lisboa, IN-CM, 1972 [reprodução fac-similada da edição de 1685 e 1689]. Uma boa parte deste Discurso já se encontra no Prólogo de M. de Faria y Sousa, Divinas y humanas flores, primera y segunda parte. En Madrid por Diego Flamenco, 1624.

2 Cf. Clavería 1999: 115-120. En este conhecido prólogo A la Duquesa de Soma, Boscán declara-se «inventor de estas trobas, las quales hasta agora no las hemos visto usar en España», sendo consciente «de provar mi pluma en lo que hasta agora nadie en nuesta España ha provado la suya», até afirmar rotundamente: «he querido ser el primero que ha juntado la lengua castellana con el modo de escribir italiano».

3 Algumas das mais recentes observações sobre este encontro estão em Spaggiari 1992; Navarrete 1997: 84-100.

4 Cf. Pepe Sarno 2001: 279.

5 Cf. Clavería 1999: 118: «Mas esto no bastara a hazerme pasar muy adelante si Garcilaso, con su jüizio, el cual no solamente en mi opinión, mas en la de todo el mundo, ha sido tenido por regla cierta, no me confirmara en esta mi demanda».

6 Na verdade Boscán, «apoyado en la autoridad que el toledano tenía en 1542, cinco años después de su muerte, convierte la adhesión del joven Garcilaso a su intento de 1526 en 'confirmatio' de su propia opinión» (Armisén 1982: 147). Sobre o proveito que o próprio Boscán tirou das viagens de Garcilaso a Itália, veja-se Gargano 1988. 
Logo a seguir, Faria y Sousa menciona os poetas italianos do séc.XIII e começos do XIV «que andan todos juntos (y otros inciertos) en un pequeño Tomo impresso en Florencia el año $1527 \gg .{ }^{7}$ Este «pequeno tomo» pode ser seguramente identificado como sendo a recolha de Sonetti e canzoni di diversi antichi autori toscani. ${ }^{8}$ Comumente chamada de Giuntina di rime antiche, esta foi a primeira antologia metódica que reúne sonetos e canzoni de Dante e de seus predecessores, ${ }^{9}$ a começar pelos poetas sicilianos, os quais, conforme recorda Faria y Sousa (§ 4), são considerados como sendo os diretos continuadores dos provençais:

de los Provenzales, y Alvernos, de quien se cree los tomaron primero los Sicilianos, según Petrarca (en la epist. ad Socrat. suum) de quien dize que fueron allá primeros en lo de escrivir versos en su vulgar idioma.

A remissão de Faria y Sousa é para Petrarca, Familiarum Rerum libri, I,1 Ad Socratem suum, ${ }^{10} \S 6$ : «Quod genus, apud Siculos, ut fama est, non multis ante seculis renatum, brevi per omnem Italiam ac longius manavit, apud Grecorum olim ac Latinorum vetustissimos celebratum; siquidem et Athicos et Romanos vulgares rithmico tantum carmine uti solito accepimus». ${ }^{11}$

Faria y Sousa não se satisfaz, contudo, com esta opinião (§ 4): «Pero aora mostraré yo que los versos de onze sílabas, o endecasílabos, no sólo son más antiguos en España de lo que pensó Herrera, sino que Italia los tomó della». Como vamos ver a continuação, 'Espanha' para ele significa, de fato, Portugal.

7 É a propósito deste volume que Sarmiento faz a alusão seguinte: «El mismo Faria dá noticia de una colección de Poetas italianos anteriores al Dante, que no he visto»; cf. Sarmiento 1775: 222-23.

8 Sonetti e canzoni di diversi antichi autori toscani in dieci libri raccolte (...). Impresso in Firenze per gli heredi di Philippo di Giuntina nell'anno del Signore 1577. Adì vi. del mese di Luglio.

9 Publicada por Bardo Segni, esta edição está repartida em 11 livros. Os autores, desde Dante até ao imperador Frederico II e ao rei Enzo, seu filho, aqui estão enumerados exatamente na mesma ordem que se encontram em Faria y Sousa.

10 Trata-se, como é sabido, de Ludovico Santo de Beringen, a quem Petrarca conheceu em Avinhão.

$11 \mathrm{O}$ assunto incide propriamente na métrica românica, com base nos acentos e na contagem silábica: Petrarca coloca-a em relação com a antiga poesia latina em verso saturnio, pelo qual remete para Servio, Ad Georg. 2.385. A este juizo de Petrarca faz-se alusão na carta dedicatória à chamada Raccolta aragonese: cf. Dotti 1991: 4-5 (texto) e 89 (notas). Veja-se também Boscán (Clavería 1999: 120): «Porque los hendecasíllabos, de los cuales tanta fiesta han hecho los latinos, llevan casi la misma arte, y son los mismos, en cuanto la diferencia de las lenguas lo sufre». 
2. Dentre os poetas ibéricos mais antigos que Santillana, Faria y Sousa menciona Auzias March ${ }^{12}$ assim como o Infante Dom Pedro de Portugal, ${ }^{13}$ filho de D.João I, «y antecedente al de Santillana, pues se carteava con Juan de Mena (como consta de sus obras)»: ${ }^{14}$ dele nos restam dois sonetos, ${ }^{15}$ sendo o primeiro composto em louvor de «Vasco de Lobeyra Cavallero Portugués, ${ }^{16} \mathrm{e}$ inventor de los libros de Cavallerías con su Amadís» ${ }^{17}$ (o mesmo é reafirmado na Crónica do conde Don Pedro de Meneses, ${ }^{18}$ escrita en 1454). Depois de ter advertido que outros atribuiram este soneto ao rei Afonso IV ( $† 1357)$, Faria y Sousa finalmente informa: «agora hallé en un manuscrito, que el Soneto es

12 Auzias March «fue muy anterior al Marqués de Santillana (...). Y por aquí queda claro que en Castilla, Valencia, y Cataluña avia poemas deste género mucho antes no sólo que Boscán y Garcilasso, sino que el propio Marqués de Santillana».

13 Nascido em Lisboa, a 9 de Dezembro de 1392; falecido na Batalha de Alfarrobeira, a 20 de Maio de 1449; sepultado no Mosteiro da Batalha. Primeiro duque de Coimbra, casou a 13 de Setembro de 1429 com D. Isabel de Urgel. Foi regente do Reino de 1438 a 1446. «Juan de Mena lo tuvo en alta consideración y la literatura popular del siglo XVI lo convirtió en el príncipe que había recorrido las siete partes del mundo». Autor do Livro da Virtuosa Benfeitoria (em colaboração com seu confessor frei João Verba), da tradução do Livro dos Ofícios de Cícero, assim como de outras muitas obras, hoje perdidas (Fernández Sánchez/Sabio Pinilla 1999: 62). Quanto à autoria contestada duma das suas obras mais conhecidas, veja-se ultimamente Sánchez Lasmarías 2008.

14 Faria y Sousa refere-se com certeza a dois poemas inseridos no Cancioneiro Geral de Garcia de Resende, no primeiro dos quais Juan de Mena presta homenagem à vertente viajeira do infante; veja-se a edição de Dias 1990, II: 85-88 (Do Ifante Dom Pedro, filho d'el-Rei Dom Joam, em louvor de Joam de Mena, e Reposta de Joam de Mena, à qual Reprica o Ifante).

15 Cuja atribuição à D. Pedro já se encontra em M. de Faria i Sousa, Fuente de Aganipe o rimas varias (...) divididas en siete partes. En Madrid: por Carlos Sánchez Bravo, 1646, cf. Prólogo § 8-9.

16 Vasco de Lobeira escreveu, em 3 livros, uma redação de Amadis, hoje perdida: a única versão ainda existente, foi composta em língua espanhola por García Ordóñez de Montalvo, governador de Medina del Campo, quem a escreveu entre 1492, data da ocupação de Granada, e 1504, data da morte de Isabela de Castilha. Editada em Saragossa (1508, em 4 livros), ela foi reproduzida na Biblioteca de Autores Españoles (Rivadeneyra), vol.40, 1857; ver a nova ed. de Place 1959-1969.

17 Armado cavaleiro depois da batalha d'Aljubarrota (1385), morreu em 1404. Quanto ao autor e à língua d'Amadis de Gaula em sua versão originária, o problema está exposto com muita clareza em Saraiva/Lópes 1989: 95-98. Sobre Amadís veja-se o recente artigo de Colán 2007-2008: 779-89.

18 Primeiro capitão de Ceuta; escrita a pedido da duquesa de Bragança, sua filha. Cf. Zurara 1792; King 1978 (ed. diplomática); Zurara 1988 (repr. fac-similada). Gomes Eanes de Zurara (ou Azurara) foi nomeado cronista por Afonso V em 6 de julho de 1454 e serviu até 2 de abril de 1474, pouco antes de morrer. 
del mismo Lobeyra». Na realidade, esses dois sonetos figuram nos Poemas Lusitanos de Antônio Ferreira, ${ }^{19}$ sendo, como podemos ler no ms., redigidos em lingoagem antiga. $\mathrm{O}$ primeiro dos dois foi igualmente trasmitido pelo Cancioneiro de corte e de magnates ${ }^{20}$ assim como pelo Cancioneiro do Padre Pedro Ribeiro. ${ }^{21} \mathrm{O}$ texto de Faria y Sousa reproduz fielmente o soneto presente na edição dos Poemas Lusitanos de 1598; enquanto à atribuição ao Infante Dom Pedro, Faria y Sousa deve ter recorrido à um dos dois Cancioneiros mencionados. ${ }^{22}$ Em contrapartida nenhum dos códices atribui o soneto a Lobeira. Quanto à atribuição à Afonso IV, é preciso lembrar-se que, na versão portuguesa original, o protagonista do romance Amadis de Gaula, na esteira do seu modelo Lancelot, havia sido apresentado como sendo absolutamente fiel à Oriane, sua amada: tanto que, quando a rainha Briolania fez ao cavaleiro alguns avanços, Amadis permaneceu insensível. Foi o rei Afonso de Portugal quem interviu, fazendo assim com que o autor modificasse seu texto: temos então na sua versão portuguesa posterior, um Amadis que cede aos charmes de Briolanie e, com a permissão de Oriane, faz-lhe duas crianças.

De fato, ambos sonetos reproduzidos por Faria y Sousa «hablan de Brioranja»; e no primeiro, o autor pede a Vasco Lobeira de tornar essa personagem menos desafortunada:

Maes porque vos figestes a fremosa

Brioranja anar endoado ${ }^{23}$ hu nom amarom,

Esto combade,$^{24} \&$ contra $^{25}$ sâ vontade.

Ca heu hey muy ${ }^{26}$ gram dó de a ver queyxosa,

Por sâ gram fremosura, \& sâ bondade,

E her porque ó fim amor nom lho pagarom.

19 Earle 2000: 95-96.

20 Askins 1968: 297. Abreviado CCM por Earle 1990: 509, mas por $E$ no aparato do seu texto crítico, p. 95 e p. 297 ( «Soneto Do Infante Dom P. ${ }^{\circ}$ a Vasco do Lobeira do que fez»).

21 Castro 1988: 167 ( «Infante D. $\left.\mathrm{P}^{\circ} »\right)$.

22 A variante figestes, dada por Faria y Sousa no v.9, se aproxima de figuestes que podemos ler em $C P$.

23 endoado 'em vão': age como fator dinâmico, porque $E$ o transforma em enloado, enquanto no texto de $C P P$ ele não aparece.

24 De fato cambade nos Poemas Lusitanos (cambrai E, cambai PPR).

25 De fato compra nos três mss.

26 Provavelmente foi adicionado por Faria y Sousa, para remediar à aparente hipometria Cá eu hei grã dó de a ver queixosa no texto dos Poemas Lusitanos, à qual também reagiram os dois autros mss, cf. Porque eu E: Perque eu ei her PPR. Será necessário então supormos $v<e>$ er no original. 
Quanto ao segundo soneto, onde podemos ver Briolania exercer sua vigança sobre o Amor, Faria y Sousa afirma que se trata de uma «tradución de Petrarca». De fato, tanto Carolina Michaëlis de Vasconcellos quanto Adrien Roig (1978) propuseram como fonte o Trionfo della Pudicizia de Petrarca; Earle, por sua parte, declara não estar de acordo. ${ }^{27}$

Publicados em 1598, estes dois sonetos atribuídos a Lobeira são, segundo Carolina Michaëlis, a causa objetiva das invenções literárias que foram inseridas, quatro anos depois, na Crônica de Bernardo de Brito.$^{28} \mathrm{Com}$ efeito, é com os dois sonetos que Faria y Sousa termina, en 1624, a parte do Prólogo às Divinas y humanas flores consagrada à questão do decassílabo: «Assí que parece que primeros que Italianos, imitaron Portugueses a los Provençales, o por lo menos son los primeros que en España exercitaron esta poesía». ${ }^{29}$ Ainda estamos aquém da mistificação creada por Brito, e Faria contenta-se com afirmar que os Portugueses fueron os primeiros a imitar a versificação dos trovadores provençais.

3. Finalmente, quanto ao emprego dos decassílabos na península ibérica na época de Dante, Faria y Sousa remonta a Don Juan Manuel, príncipe da Espanha ${ }^{30}$ e autor do Libro de Patronio o Conde Lucanor (1325), como também a Dom Dinis. ${ }^{31}$

27 Earle 1990: 204; cf. Id. 2000: 510: «É uma composição frívola, com evidentes paralelismos temáticos, como aliás nota Roig, com alguns dos epigramas de Ferreira».

28 Vasconcellos 1897: 165.

29 É este prólogo que José Pellicer menciona ao encarar a mesma questão: «Allá Manuel Faria en un prólogo de sus Flores pleitea, Portugués al fin, que el origen de la octava rima, y sonetos, se les deve a los Portugueses, porque a un tiempo mismo de los Provençales y Alvernos lo imitaron ellos y los Italianos, pues fueron de una era el Dante en Italia año de 1265, y el Rey don Dionís de Portugal año de 1261 (...): y assí no quiero yo creer que fuesse imitación de Italia, sino conservación de lo que Portugal, troço no el menos ilustre de España, observó de los Provençales y Alvernos. Y si el Marqués fue el primero que escrivió Endecasílabos Castellanos, nos es cierto que imitó a los de Italia, pues en su tiempo ya andavan públicos los versos de onze sílabas, que el Infante don Pedro de Portugal escrivió, de los quales refiere algunos Manuel Faria. De que puede colegirse, que el Marqués imitó a Portugal, y no a Italia, pues a un tiempo mismo estudiaron el Ritmo de los Provençales, Italianos, y Portugueses. Sea pues quien fuere el primero, en este género de canto se ha escrito en España lo más valiente de su poesía» (Salas y Tovar 1971: 3).

30 «Don Juan Manuel Príncipe estudioso, y elegante, que vivió en Castilla por los años del Reynado de D. Pedro en Portugal (cuyo fallecimiento fue el de 1367) trae en su Conde Lucanor algunos versos Castellanos deste número, de que se ve que entonces se escrivian en Castilla».

31 ««El Rey Don Dionís de Portugal nació primero que el Dante tres, ó quatro años, y escrivió mucho deste propio género Endecasílabo, como consta de manuscritos». 
No Conde Lucanor cada conto exemplar dito pelo conselheiro Patronio se termina por dois versos finais (moraleja), que servem para resumir a sentença pronunciada na conclusão. Estes versos, dos quais a qualidade é em geral moderada, estão em medidas diferentes. Eis aqui os decassílabos presentes na obra: ${ }^{32}$ En [el] comienço deve omne partir/El danno, que non le pueda venir

Si non sabedes que devedes dar,/A grand danno se vos podria tornar Non te espantes por cosa sin rrazon/Mas defiendete bien commo [fuerte] varon Quien te mal faz mostrando grand pesar,/Guisa commo te puedas del guardar Por quexa non vos fagan ferir,/Ca siempre vence quien sabe sofrir

Non te quexes por lo que Dios fiziere,/Ca por tu bien seria quando el quiziere.

Embora, no nível da cronologia, estes autores sejam, segundo Faria y Sousa, quer contemporâneos, quer mesmo anteriores a Dante, «todo esso (aun siendo anterior a Boscán, y a Garcilasso com más de 200 años) pudo ser a imitación de Italia, pues el Emperador Federico, de que se hallan semejantes versos, vivió por los años 1200 que son ciento antes de los en que florecía El Rey Don Dionis». Contudo, continua Faria y Sousa, não são os italianos que podem felicitar-se do fato de terem composto os primeiros poemas com versos decassílabos, mas sim «los Lemosines, o Valencianos», e nomeadamente Jordi de Sant Jordi. Faria y Sousa já o tinha sugerido no § 6:

Lo que se sabe es que Petrarca imitó mucho de Mossén Jordi Poeta Lemosino, o Valenciano, o, para mejor dezir, le trasladava. Assí lo afirma Pedro Antón Beuter en su Dedicatoria de su Corónica General, y trae de aquel Autor estos versos:

E no he pau, e no tinch quim guarreig.

Vol sobrel cel, e non movi de terra.

E no estrench res, e tot lo mon abrás.

Hoy he de mi, e vull altri gran bé.

Si no Amor, donç aço que sem.

Y essos cinco versos son en Petrarca, por su orden, estos:

Pace non trovo, e non ho da far guerra.

E volo sopra il cielo, e ghiacio in terra.

E nulla stringo, e tutto 'l mondo abraccio.

Et ho in odio me stesso, \& amo altrui.

S'amor non è, che dunque è quel ch'io sento.

32 Cf. Knust 1900: 35, 39, 55, 57, 65, 73. Ver também a edição de Blecua 2003. 
De aquí se ve que los endecasílabos no sólo eran más antiguos en España que Petrarca en Italia, sino que el mayor Lýrico Italiano trasladava de uno Español. Y también es cierto que Mossén Jordi no fue acá el inventor destos versos, sino que escrivia en los que hallava usados en su Patria.

Faria y Sousa, no $\S 12$, retoma o argumento:

Mas porque no quitemos a nadie su gloria, digo que hasta aquí pudieron Portugueses, y Castellanos imitar a los Lemosines, o Valencianos; porque esse Cavallero Mossén Jordi (de quien Petrarca trasladava) florecía, según Beuter, por los años 1250 reynando Don Jayme, el famoso, de cuya casa fue: con que es anterior no sólo a Boscán con algunos cientos de años, y al de Santillana con mucho, y a Don Juan Manuel, sino a Petrarca con más de ciento: y al Rey D. Dionís, que no era nacido quando él poetava, casi contemporáneo del Emperador Federico segundo. Dize allí Beuter que escrivió Sonetos, Sextinas, y Terceroles, que son todas las suertes de composición del Petrarca, menos las Canciones. Repárese que Terceroles es lo que oy llamamos Tercetos, de que algunos quieren que Dante fuesse el inventor, y no es assí, pues el Jordi los escrivía quando aun Dante no era nacido. De otro Cavallero de los mismos dias, llamado Mossén Febrer, dize (tambien allí) el Beuter, que compuso en Sonetos la tormenta que el Rey D. Jayme corrió en el mar aquel año de 1250 hallándose ambos estos Poetas en ella. Gran ventaja, por cierto, de los Valencianos en la antigüedad de Poetas con este número!

Neste caso, a fonte de Faria y Sousa foi Padre Antonio Beuter, teólogo e cronista valenciano, na nota adicionada à tradução de sua Primera part de la història de València (1538), imprimida em Valência no ano de 1546 e intitulada Corónica general de España y especialmente del Reyno de Aragón, Cataluña y València. Como justificação desta tradução para uma língua estrangeira, Beuter faz um elogio da língua catalã e de seu prestígio. ${ }^{33}$ Vejam-se a seguir as duas passagens de Beuter utilizadas por Faria y Sousa: ${ }^{34}$

el Petrarca se aprovechó y hurtó de la trobas de un nuestro cavallero valenciano, que fue quasi cient años primero que el Petrarca escriviesse, y usó sonetos y sextiles y terceroles en nuesta lengua valenciana limosina. $Y$ aunque pudiesse poner aquí muchas pruevas desto que escrivo, tengo que abastará lo que aquí quiero poner, porque se sepa la verdad del negocio (...). Este mossén Jordi

33 Se trata de um exemplo de «apologia compensatòria de la llengua valenciana», como diz Valsalobre $2007: 11$.

34 Epístola, in Corónica 1546 cit. Reproduzimos a transcrição de Valsalobre 2007: 5. 
fue un cavallero cortesano del rey don Jayme que ganó Valencia, y se halló con él en el passaje de ultramar que se desbarató por la tormenta que le tomó enfrente de Mallorca, año MCCL quasi o poco más. Y un otro cavallero su compañero, que se llamava mossén Febrer, hizo unos sonetos descriviendo aquella tormenta. ${ }^{35}$

Como já foi constatado, ${ }^{36}$ os quatro primeiros versos de Petrarca citados por Beuter e, na sequência dele, por Faria y Sousa, correspondem aos versos 1, 3, 4 e 11 do soneto Rvf 134, enquanto o último verso citado reproduz o incipit do soneto Rvf 132 . No tocante a Jordi, os versos citados são respectivamente os vv. 44, 6, 5 e 12 da Cançó d'opòsits, enquanto o último verso - adicionado por Argote de Molina ${ }^{37}$ - não se encontra em nenhum dos poemas de Jordi que chegaram até nós. 38

4. Como Valsalobre argumenta (p. 8-9) de forma muito persuasiva, os componentes principais da invenção confeccionada por Beuter remontam todos a Íñigo López de Mendoza, marquês de Santillana, e notadamente a seu Prohemio e carta qu'el Marqués de Santillana enbió al Condestable de Portugal con las obras suyas, escritos em meados de $1446 .{ }^{39}$ De fato, Santillana se limita a mencionar uma canção de Jordi, sem precisar que nela se encontram alguns versos que derivam, incluindo o incipit, dum soneto de Petrarca: ${ }^{40}$

35 Este fato aconteceu, como foi estabelecido por Riquer, em setembro de 1398; cf. Valsalobre 2007: 5 n. 10. Em todo o caso, Jordi e Febrer participaram juntos, em 1420, na expedição de Afonso o Magnânimo para a Córsega e a Sardenha. Jordi morreu em 1424, entre 12 e 15 de junho segundo Villalmanzo Cameno 1993; ou, mais precisamente, 18 junho: ver Chiner Gimeno 1999.

36 Riquer/ Badia 1984: 222; Duran 1991: 253.

37 Cf. abaixo, nota 40. Este verso corresponde evidentemente à $R v f$ 32,1 (Riquer/ Badia 1984: 222).

$38 \mathrm{O}$ exemplar do manuscrito do qual Beuter se serviu poderia ser próximo do ms. $\mathrm{P}$ (Bibl. Univ. de Saragossa, ms. 184), assim como sugere Valsalobre 2007 :6, com base nas variantes tinch (v.1) e altri (v.4). O texto de Beuter permete corrigir alguns erros presentes no texto de Faria y Sousa, a saber, nom em lugar de non no v.2, enquanto o último verso deve ser lido Si no.s amor, dons açò que serà.

39 Santillana é igualmente autor da Coronaçión de Mossén Jordi, onde Jordi é colocado no mesmo nível que Homero, Virgílio e Lucano, e somente um grau abaixo de Dante. Cf. Riquer/Badia 1984: 314-19; Cabré 1998: 25-38.

40 «Els ressons de Petrarca es creuen en el text amb d'altres de Folquet de Marselha i de Giraut de Bornelh» (Riquer/Badia 1984: 221). 
En estos nuestros tienpos ${ }^{41}$ floresçió mosén Jorde de Sant Jorde, cavallero prudente, el qual çiertamente conpuso asaz fermosas cosas, las quales él mesmo asonava, ca fue músico músico excellente; fizo entre otras una 'cançión de oppósitos’ que comiença: Tos iorns aprench e desaprench ensems; fizo la Passión de amor, en la qual copiló muchas buenas cançiones antiguas, asý destos que ya dixe commo de otros. ${ }^{42}$

Esta mistificação feita por Beuter ${ }^{43}$ foi retomada primeiramente por Gaspar Gil Polo no catálogo de poetas ${ }^{44}$ que se encontra na Diana enamorada (1564), onde ele se refere, pela primeira vez, a Jorge del Rey; logo por Gaspar Escolano, ${ }^{45}$ e um século depois, por Antoni de Bastero, cônego de Girona exilado na Itália, no prefácio de sua Crusca provenzale (Roma, 1724); ${ }^{46}$ finalmente por Augustí Sales em seu Juicio sobre o Diccionario valenciano-castellano de Charles Ros (Valencia, 1764). ${ }^{47}$

Fora de Valência, foi primeiramente Gonzalo Argote de Molina quem se fez eco da invenção de Beuter, em seu Discurso sobre la poesía castellana pelo qual começa a sua edição d'El Conde Lucanor. ${ }^{48} \mathrm{E}$ foi justamente à margem do comentário de Argote y Molina sobre a poesia de Boscán que

41 Como estabeleceu Cabré 1998: 30-32, o Marquês se refere aos anos de 1420, quando ele esteve em contato com os poetas da corte de Margarida de Prades e do jovem Afonso. A 1420 justamente remonta a investidura de Jordi como cavaleiro.

42 Gómez Moreno 1990: 59. A referência «de otros» concerne Guillem de Berguedà, Pau de Bellviure e Pere Marc, aos quais Santillana já fez alusão. De fato, na Passio amoris de Jordi não existe qualquer menção aos mesmos.

43 «Tot i amb tot, parlant amb propietat, la 'proposta' de Beuter no és una falsificació en sentit estricte (és a dir, la confecció d'un text nou 'acabat de trobar' atribuït a un personatge remot). Potser seria més just dir-ne tergiversació. Tergiversació interessada, és clar. Una mistificació, si voleu» (Valsalobre 2007: 10).

44 Os catálogos versificados dos escritores valencianos da segunda metade do século XVI constituem, como diz Valsalobre, «un gènere característicament valencià».

45 Década primera de la historia de la insigne y coronada ciudad y Reyno de Valencia (Valencia, 1610-1611), no cap. XIV De la lengua limosina y valenciana, p. 89-91. Em Valsalobre 2007 encontra-se uma vasta lista de todos os que se fizeram eco da teoria de Beuter.

46 Quanto à atitude mais precisamente cética de Bastero sobre este assunto, ver Valsalobre 2007: 17.

47 O texto foi editado por Bertran 2004: 108-17.

48 Obra de D. Juan Manuel (1282-1349?), descoberta e publicada por Gonzalo de Argote de Molina em Sevilha, 1575, ff. 92-97. Veja-se Tiscornia 1995. 
Menéndez y Pelayo relembra a difusão da invenção de Beuter ${ }^{49}$ que passou primeiramente para as mãos do polígrafo castelhano Juan Caramuel,,$^{50} \mathrm{e}$ logo depois chegou até Faria y Sousa. ${ }^{51}$

O primeiro a dar-se conta, em suas Memorias, da contradição que existe, de fato, entre Beuter e Santillana, foi o beneditino Martín Sarmiento, pseudônimo de Pedro José Garcia Balboa, originário da Galícia. ${ }^{52}$ Seu pensamento foi seguido por Tomás Antonio Sánchez. ${ }^{53}$ Como reação a esta dúvida criada sobre uma teoria que sempre fora aceita de forma unânime, o erudito valenciano Francisco Cerdà y Rico postula a existência de dois Jordis ${ }^{54}$ uma escapatória que gozou de um sucesso considerável. ${ }^{55}$

Quanto à Andreu Febrer, em lugar de «unos sonetos» (como Beuter diz), foi questão de uma 'canção' de agradecimento à Santa Virgem por ter o autor escapado são e salvo de uma tempestade (Pus qu'estorts suy del lach de la mar fonda): Febrer a compôs provavelmente em setembro de 1388. ${ }^{56}$ Manipulando uma vez mais os dados históricos, Beuter confundiu conscientemente este episódio com uma circunstância parecida que aconteceu em 1269, na altura de uma cruzada na Terra Santa que acabou por fracassar. ${ }^{57}$

49 Como já o tinha estabelecido Sarmiento 1775: 219: «Este pasage de Beuter le copiaron Argote, Escolano, Faria, Caramuel, y don Nicolás Antonio; y así se hizo vulgarísima la especie de que el Petrarca habia copiado a Mosen Jordi».

50 Primus calamus ab oculos ponens metametricam quae (...) multiformes labyrinthos exornat, Roma, 1663, ff. 44 et 104. A notar que Caramuel atribui tanto a Jordi, como a Febrer, a nacionalidade portuguesa.

51 Menéndez y Pelayo 1908: 169-76. Na mesma trilha de Ortís (ou Ortiz), Menéndez y Pelayo supõe como possível a existência de um poeta contemporâneo de Jaume I, denominado Jorge (ou Jordi) del Rey; ver Valsalobre 2007: 22.

52 Cf. Gómez Moreno 1983: 89-90.

53 Sánchez 1864. Edição original: Colección de poesias castellanas anteriores al siglo XV. Preceden noticias para la vida del primer Marqués de Santillana y la Carta que escribió al Condestable de Portugal sobre el origen de nuestra poesía. Ilustrada con notas por D. Thomás Antonio Sánchez bibliotecario de S.M., Tomo I (Poema del Cid), en Madrid: por D. Antonio de Sancha, año de m. dcc. lxxix. (os demais tomos sairam em 1780, 1782, 1790).

54 Notas al 'Canto de Turia' (1778 [1780]) anexadas à sua edição de Gil Polo (= Rico 1778).

55 Ver. Aramon i Serra 1997: 509-10. Durante o século XIX, até se supôs a existência de três Jordis, ver Valsalobre 2007: 27. Foi Manuel Milà i Fontanals que chegou a resolver esta questão de maneira definitiva. Cf. Massó Torrents 1902: 24-25.

56 Cf. Riquer 1951: 11-12.

57 Cf. Valsalobre 2007: 5 n. 11; 8 n. 19. 
5. Apesar dos elogios endereçados aos outros catalãos, Faria y Sousa, como acima foi dito, tampouco estava disposto à abonar-lhes o privilégio de ter utilizado pela primeira vez os versos de onze sílabas (§ 13):

Pero no me sossiego con esta ventaja, y quiero mostrar que casi cien años antes della, y del Emperador Federico, y de Jordi, y de Febrer, se escrivían en Portugal versos de onze sílabas. Porque antes de passar allás Don Enrique con título de Conde (que fue por los años de 1090) se escrivían allá, pues de aquel tiempo permanecen Canciones, de que dexaremos aquí por exemplo una estancia:

Ouroana, Ouroana, oy tem por certo

Que $<$ m $>$ inha vida, \& viver,

Se alvidrou por teu alvidro, porque em cabo

$\mathrm{O}$ que hey de la chebone sem referta,

Mas no' ha porque se ver, \&c.

Era Autor destas Poesías (bien semejantes a algunas de agora en no entenderse, aunque allá lo hizo el tiempo, y acá el desatino) Gonçalo Hermíguez Cavallero valeroso de aquel siglo, y escrivíalas a su muger Oroana. Tráelas el Doctor Fray Bernardo de Brito Coronista Mayor del Reyno, ${ }^{58}$ y de su Orden, Varón célebre, en su Historia de Cister. ${ }^{59}$

A obra de Brito à qual Faria y Sousa se refere é a Primeira Parte da Chrónica de Cister ${ }^{60}$ nomeadamente no Livro Sexto, capit. 1 Da fundação

58 Bernardo de Brito (1569-1617) nasceu e morreu em Almeida. É na Abadia de Alcobaça que ele pronuncia seus votos religiosos. Doutor em teologia pela Universidade de Coimbra, foi nomeado cronista oficial de Portugal depois da morte do Doutor Francisco de Andrada, seu predecessor. Formulou o projeto de escrever a história de seu país desde as origens em oito partes, com o título de Monarchia Lusitana ; contudo, ele apenas consegue publicar as duas primeiras partes (1597 e 1609). Depois da sua morte, sua obra foi continuada pelo seu colega Francisco António Brandão, autor da terceira, quarta (1632) e quinta parte (1650) da Monarchia Lusitana.

59 Todo este parágrafo de Faria y Sousa que se refere à origem do decassílabo foi reproduzido por Pulsoni 2006: 294-95, sem todavia abordar nenhum dos problemas dos quais tratamos em nosso trabalho.

60 Primeyra parte da Chronica de Cister: onde se contam as cousas principais desta religiam com muytas antiguidades, assi do Reyno de Portugal como de outros muytos da christandade (...) Em Lisboa, Crasbeek, 1602. A obra foi objeto de mais uma edição, cf. Brito 1720. Brito publicou ainda os Elogios dos Reis de Portugal (Lisboa, Crasbeeck, 1603) e o poema Sylvia de Lisardo (ibid., 1597). 
do mosteiro de santa Maria dos Tamaraes que he da filhação de Alcobaça, tocãose alguas antiguidades notaveis, f. 373-74:

$\&$ no baptismo mudou o nome de Fatima em Oriana Hermiguez, como lhe chama a memoria de que vou tirando esta historia. Tão estranho foi o amor que ambos se tiverão, que por maravilha se falava nelle em Portugal, \& o mostrão bem alguns versos que lhe fazia de que porey algus, que tem lugar em qualquer obra, por se ver nelles os mais antigos termos da lingoa Portuguesa.

Tinherabos, nam tinherabos,

Tal a tal ca monta!

Tinheradesme nom tinheradesme,

De la vinherades, de ca filharades

Ca amabia tudo em soma.

Per mil goivos trebelhando,

Oy oy, bos lombrego

Algorem sé cada folgança

As mei eu: perque do terrenho

Nom ahi tal perchego,

Ouroana, Ouroana, oy tem per certo

Que inha bida do biver

Se alvidrou per teu alvidro per que em cabo

$\mathrm{O}$ que eu ei de la chebone sem referta,

Mas não ha perque se ver.

Com estas invenções de verso, \& outras semelhantes que deixo de referir por bastarem estas para meu intento, solemnizava Gonçalo Hermiguez os amores de sua querida Oriana.

A notar que Faria y Sousa já tinha evocado este texto em 1627, na sua obra Musa nueva, ${ }^{61}$ e precisamente numa introdução em que, mais uma vez, tenciona afirmar a superioridade da língua portuguesa: «Los versos de España son tan hijos de Portugal que hasta los mismos Castellanos quando los escrivían era en lengua Portuguesa: claramente se prueva de algunos escritos en la librería del Escurial». A propósito, Faria menciona un «Tomo

61 M. Faria i Sousa, Musa nueva. Parte sexta de sus Rimas. Dedicada a la patria, Madrid, Diego Flamenco, 1627. Cf. Pulsoni 2009. 
de varios poemas del Rei don Alonso el Sabio, ${ }^{62}$ y otro de Macías»; ${ }^{63}$ deste último refere algunas passagens Argote de Molina «en el lib. 2 de la Nobleza de Andaluzía». ${ }^{64}$ Além disso, Faria afirma que D. Dinis precedeu Dante no emprego do hendecassílabo ( «los versos que llaman Italianos»), ${ }^{65}$ e de qualquer forma, os Italianos escreveram as próprias canções «a imitación de las coplas antiguas de España», naturalmente escritas em português «avrá quinientos años».

Para comprovar a sua afirmação, Faria y Sousa reproduz alguns versos dispersos das Cartas de Egas Moniz, que considera equivalentes aos versos duma canção: «Que cosa es esta suerte de coplas com versos enteros y quebrados sino Canciones $?^{66}$ A que los Italianos no dieron mayor novedad que passarlas desde nuestros versos pequeños a los suyos. Pero ni esto les quiero conceder» : com efeito, avançando o raciocínio que iria desenvolver mais amplamente no Discurso inserido nas Rimas várias, Faria acrescenta «que de más de seyscientos años a esta parte se escrivieron em Portugal, de once sílabas como oy, y Canciones como las de Italia», e como prova disso, apresenta a última estrofe da canção de Hermiguez.

Dois anos após a saída da Musa nueva, Miguel Leitão de Andrada publica na íntegra a Trova dos Figuereidos, as Oitavas na lingoagem antiga quando se perdeo Hespanha, e as duas Cartas de Egas Moniz (Fincaredes bos embora e Bem satisfeita ficades). ${ }^{67}$

62 Tratar-se-á do códice T.I.I. de la Biblioteca del Monasterio de El Escorial, um dos quatro manuscritos que transmetem as Cantigas de S. Maria: este representa a redação mais vasta, de 402 textos, na que se baseiam as edições modernas. Edição fac-similada: Madrid, Edilán, 1979, 2 vols.

63 Autor de poemas líricos, floreceu entre 1340 e 1370; a sua obra teve ampla circulação nos cancioneiros do séc. XV. Segundo a lenda que se formou em torno dele, foi morto por um marido ciumento, tornando-se desta forma numa espécie de mártir do amor. Veja-se Avalle-Arce 2001: 177-88.

64 Sevilla, Fernando Díaz, 1588; veja-se a edição de Garnica 1957.

65 «Los primeros versos de la medida que algunos llaman Italiana que es la Endecasílaba se hallan en Portugal con tanta antigüedad que antes parece lo imitaron de los Portugueses los Italianos i Provençales, como evidentemente lo provamos en el Prólogo de la Sexta parte de nuestras Rimas de Fuente de Aganipe»: M. de Faria i Sousa, De las Primazias deste Reyno en diferentes Artes, Cosas i Puestos, in Europa portuguesa, segunda edición (...), Lisboa, Antonio Craesbeeck, 1678-1680, pp. 367-76, ponto 64.

66 Trata-se, na verdade, de versos de redondilha maior, que alternam com octossílabos quebrados.

67 M.L. de Andrada, Miscellanea do sitio da Nossa Senhora da Luz do Pedrogão grande (...), Lisboa, Matheus Pinheiro, 1629. Citamos da 'nova edição correcta', Lisboa, 
Finalmente, no último dos três tomos da sua obra póstuma Europa portuguesa, Faria y Sousa publica na íntegra ${ }^{68}$ as quatro oitavas do «Poema de la pérdida de España»; ;9 as três estrofes da «canción de Gonçalo Hermíguez, cavallero valeroso de los últimos años de nuestro primer Rey, escrita a su muger Ouroana»; e as duas Cartas de Egas Moniz Coelho, «primo del gran Ayo del propio Rey primero (...), enamorado de Doña Violante, dama de la Reyna Doña Mafalda».70

A propósito da Canção de Hermingues [sic] ou de Traga Mouros, Teófilo Braga na sua História da literatura portuguesa,${ }^{71}$ mas primeiramente em outras obras, ${ }^{72}$ e notavelmente em seu Curso (pp. 142-43), relembra que esta canção foi publicada pela primeira vez por Bernardo de Brito,

que a revestiu de circunstâncias lendárias, que fizeram com que se lhe atribuisse a própria composição métrica. Ela achava-se no Cancioneiro do Doutor Gualter Antunes (ou de Marialva) e na lição de Brito há erros e transposições de versos, que um falsário não se lembrava de engendrar.

Imprensa Nacional, 1867, Diálogo I, p. 25-26 e Diálogo XVI, p. 333-37. «Se da un lato si può supporre che queste Cartas già girassero, sebbene incomplete, per iniziativa de Leitão de Andrada, dall'altro non si può escludere, anche se l'ipotesi appare poco probabile, che possa essere proprio Faria y Sousa il loro 'scopritore'. Certo è che egli non le cita interamente ma solo per tre strofi (...). Queste omissioni inducono verosimilmente a pensare che esse fossero ancora in fase di redazione» (Pulsoni 2009: 648. Textos do fragmento épico e das Cartas reproduzidos ibid: $638-43$, junto com as glosas apostas pelo próprio autor).

68 Dentro do capítulo De la lengua Portuguesa, in Europa portuguesa, cit., t. III, Parte IV, cap. IX, pp. 376-81: daqui foi retomado por Sarmiento, Balbi e a maioria dos historiadores da literatura.

69 Graças a este fragmento descobre-se, segundo Faria, «quán antiguo sea en Portugal el poetar, i assí viene a ser este escrito per ventura el de más antigüedad que se hallara en Europa».

70 Uma delas figura escrita quando o autor quita a corte para ir à Coimbra; a outra ao seu retorno, quando ele descobre ter sido enganado por aquela que lhe havia prometido fidelidade eterna. Tirando a canção de Hermiguez, os textos andam acompanhados de algumas glosas lexicais do próprio Faria. Todos têm sido reproduzidos por Pulsoni 2009: 652-56.

71 1909-1918, em 4 vols.: citamos do vol. I (Idade Média) da reedição pelas Publicações Europa-América [s.d.].

72 Persuadido da autenticidade deste pretendido cancioneiro, o erudito português se ocupou por várias vezes dele: veja-se a lista redigida por Vasconcellos 1904 :269 n. 1. Em particular, o Cancioneiro do Conde de Marialva é citado por Braga 1877 :50 entre as graves perdas causadas pela «falta de amor pelo próprio passado» que caracterizaria o espírito português (Braga 2009: 41-57). 
$\mathrm{Na}$ Canção cita-se a Chacone, que era um género poético, commum à Italia e Espanha no século XVI, e quem em Portugal apparece no povo de Friellas designando a Chacoina uma dansa mourisca, e no Alemtejo uma canção lýrica [Chacoula]. O nome de Ouroana, que também se cita neste monumento, só se usa na aristocracia portugueza do século XIV, por effeito da vulgarisação dos amores de Oriana por Amadiz. Estes amores davam logar nos poetas palacianos do século XV, a muitas composições e cançonetas, a cujo grupo pertence a Chacona de Oriana. ${ }^{73}$

Conforme recorda Teófilo Braga, o Cancioneiro do Conde de Marialva foi mencionado pela primeira vez por Bernardo de Brito, a propósito da célebre Canção do Figueiral ou romance dos Figuereidos:

E porque em matérias onde faltão Authores vale muito a tradição vulgar e as cousas que os antigos trazião entre si como authenticas e verdadeiras e as ensinavão a seus descendentes nos Romances e cantares que então se costumavão, porey parte daquelle cantar velho que vi escrito em hu Cancioneiro de mão, que foi de dom Francisco Coutinho Conde de Marialva ${ }^{74}$ e veo à mão de quem o estimava bem pouco. ${ }^{75}$

Quanto às oitavas da Perda de Espanha, Miguel Leitão de Andrada publica-as «sem declarar que eram extraídas do Cancioneiro de D. Francisco Coutinho, quando as intercalou no meio de uma novela»: assim, no seu Curso (p. 247), Teófilo Braga, acrescentando que este Cancioneiro se encontrava desaparecido até ao séc.XVIII, quando foi citado pelo Dr. António Ribeiro

73 Esta reconstrução lendária do passado nacional tinha, como é sabido, seu paralelo na Espanha: «Cette relation au passé de la péninsule se voit renforcée par une courte narration interpolée dans l'édition de la Diane: l'Historia del Abencerraje y de la hermosa Jarifa (...); dans le même temps, Ginés Pérez de Hita publie ses Guerras civiles de Granada où sont évoquées les rivalités et galanteries des Zégris et des Abencérages, qui alimentent en France les rêveries exotiques de Mlle de Scudéry et de Mme de Lafayette» (Beyrie 1994: 90).

74 «Só houve um D. Francisco Coutinho. Foi $4^{\circ}$ Conde de Marialva, pae d'aquella D. Guiomar cujo matrimonio secreto com o Duque de Aveiro e enlace publico com um filho de D. Manuel, tanto deu que fallar entre 1520 e 1530 . Morreu em 1552, sem herdeiros» (Vasconcellos 1990: 268).

75 Monarchia Lusitana [1609], cit., Parte II, livro VII, c.9, f. 296; cf. Vasconcellos 1904: 267. 
dos Santos, ${ }^{76}$ acadêmico de nome Elpinio Duriense, que o teria visto entre as mãos do Dr. Gualter Antunes, antiquário na cidade do Porto: «Vimos em tempos passados um Cancioneiro Ms., que parece letra do século XV, ${ }^{77}$ em que se tratavam Louvores da Língua portugueza». Além dos trabalhos mencionados, o Dr. dos Santos cita o fragmento do Poema da perda de Hespanha e as duas Cartas a Egas Moniz.

6. Desaparecido uma vez mais após a morte do anticário, este Cancioneiro teria sido visto em Barcelona, antes do ano de 1855, por D. Mariano Soriano Fuertes, que o descreve, com as mesmas palavras de Brito, como sendo um «Cancioneiro antigo que foi de dom Francisco Coutinho, Conde de Marialva». Ele aproveitou para acrescentar em sua história da música espanhola ${ }^{78}$ a Canção do Figueiral assim como um excerto de doze versos, A Reina groriosa. «Esta cantiga foi apontada por Amador de los Rios como pertencente a Afonso o Sábio; e de facto no livro das Cantigas de Santa Maria, publicado pelo Marquês de Valmar tem o número LXVII». ${ }^{79}$

Com relação à Canção do Figueiral, Brito tinha declarado: «e depois ouvi cantar na Beira a louradores antigos com alguma corrupção». No mesmo sentido, Miguel Leitão de Andrada acrescentou: «A qual me lembra a mim ouvil-a cantar muito sentida a uma velha de muita edade natural do Algarve, sendo eu muito menino». E Teófilo Braga, falando no seu Curso (pp. 246-47) à propósito da pretendida transcrição musical redigida por Soriano Fuertes, não fizera mais do que seguir seus predecessores: «Em

76 No Jornal da Sociedade dos Amigos das Lettras, 1836, p. 136-37 (deste jornal, publicado em Lisboa pela Typ. de J.B. Morando, saíram apenas cinco números, de Abril até Agosto de 1836): «Die hs. Abhandlung Da origem e progressos da poesia de Portugal in der er seine Meinungen darlegt, ruht in der Lissaboner Nationalbiblithek» (Vasconcellos 1897: 163 n. 3). A propósito de Ribeiro dos Santos, veja-se Aldea/Pulsoni 2006: 59-117.

77 «Doch hat er sicher geirrt. Nicht im XV., erst im XVI. und ganz besonders im Anf. des XVII. Jhs. schrieb man Werke zu Ehren der Muttersprache (Beispiel Barros und Duarte Nunes de Leão)» (Vasconcellos 1897: 166 n. 7).

78 Soriano Fuertes 1855-1869: 111-17. «Woher (...) Soriano Fuertes zu den Musiknoten gekommen ist, die er veröffentlicht, bleibt noch zu ergründen» (Vasconcellos 1897: 166).

79 Cf. Vasconcellos 1904: 268: «Soriano Fuertes, cujos juizos, em matéria literária, são de uma leveza inaudita (...), communica-a com a notação egual à que se vê nas Cantigas de Affonso o Sábio. Isso não admira, visto ser de facto obra do próprio Rei, colhida em qualquer apógrapho secundário». A propósito, Braga acusa Michaëlis de Vasconcellos de «forçar a nota irónica», e logo observa: «Em 1855 ainda não estavam publicadas as Cantigas de Santa Maria» (Braga 1870: 248 n. 1). 
que consistiria a corrupção notada na tradição oral? Da sua forma dançada em coro de estavillar, passou para a cantilena em verso de redondilha maior assonantada, que é como ainda hoje se repete no Algarve». E logo conclui:

As variantes foram notadas confrontando as lições conhecidas pelos textos do século XVII, de Fr. Bernardo de Brito e Leitão de Andrade. Por este processo ficou identificado o Cancioneiro do Dr. Gualter Antunes, ms. do século XV, com o Cancioneiro de D. Francisco Coutinho pelo sábio filólogo Dr. António Ribeiro dos Santos.

Finalmente, segundo Braga (ibid., p. 140), «temos os elementos da crítica externa para apreciar essas cinco relíquias da Poesia portugueza, sobre que tanto se tem desacertado».

Estas obras, em seu conjunto, foram por muito tempo designadas pelo nome de «as cinco relíquias da poesia portuguesa». João Pedro Ribeiro, en $1839,{ }^{80}$ já as tinha globalmente julgado como apócrifas com base em três argumentos:

1) Não existe qualquer prova da antiguidade destas obras: além do mais, muitas delas foram inseridas por Leitão em pleno meio de uma novela, onde ainda por cima uma das personagens recita um soneto de Camões, enquanto outras são publicadas por Brito, «cuja fé é nenhuma»;

2) As palavras empregadas pertencem à épocas diferentes, por isso o conjunto denota o artifício;

3) Em particular, a canção de Gonçalo Hermigues e as cartas de Egas Moniz, em comparação a outros documentos vernaculares autênticos, «se distinguem tanto em barbaridade que até nisso mostram a sua afectação».

No seu estudo sobre a poesia popular portuguesa, ${ }^{81}$ Teófilo Braga responde a cada uma das argumentações desenvolvidas por Ribeiro, anunciando que tencionava retornar mais longamente sobre o sujeito na sua Historia da literatura portuguesa:

80 Ribeiro 1810: I, 181 (Dissertação V). Pedro Ribeiro foi «die erste und vielleicht einzige, der die Unechtheit aller dieser Reliquien rund und klar ohne jeden Vorbehalt zugegeben hat» (Vasconcellos 1990: 161 n. 2). Em seguida, Herculano é que pronunciou o julgamento definitivo com respeito a estas mistificações (ibid.: 162, nota 1).

81 Braga 1911: 197-98. 
1) não é o fato de estas obras serem citadas por Leitão e por Brito, que nos autoriza a julgá-las apócrifas, tendo em vista que outras muitas obras antigas se fundam no testemunho de um só cronista;

2) a mistura lingüística pode ser a obra de vários escribas;

3) isto é ainda mais válido para as canções de Hermigues e de Egas Moniz, que são imitações dos trovadores occitanos. ${ }^{82}$

Aos argumentos de João Pedro Ribeiro, «o fundador da diplomática portuguesa» (Braga), faz igualmente alusão Alfred Morel-Fatio na sua recensão, publicada na jóvem revista Romania, ${ }^{83}$ e acompanhada duma nota do próprio Gaston Paris. ${ }^{84}$ À todas estas críticas adicionaram-se outras bem mais percutantes de Carolina Michaëlis de Vasconcellos: ${ }^{85}$

Como todos sabem, este testemunho é suspeito. $\mathrm{O}$ romance emparelha provavelmente com as demais relíquias de arte nacional, em prosa e verso, que apareceram no tempo das mudanças, maravilhosamente a ponto para favorecer certas patranhas e doutrinas históricas, genealógicas e litterárias, então em moda. Logo depois, o livro sumiu-se. Não possuimos d'elle mais signal algum. Parece todavia que resurgiu no nosso século, momentaneamente, em Barcelona, apparecendo a um musicógrapho privilegiado. Creio que em sonhos! (... $)^{86} \mathrm{O}$ texto, tirou-o evidentemente da Monarchia Lusitana. ${ }^{87}$

Mais tarde, refletindo uma vez mais sobre a questão no Grundriss de Gröber, Michaëlis exprime sua surpresa (pp. 162-63):

82 «Viterbo no Elucidario não discute a authenticidade d'ellas et diz que estes 'despedaçados restos nos informam quanto era rude e malpulida a nossa língua'» (ibid. : 12).

83 «La valeur de ces compositions (...) a été appreciée par Ribeiro, Bellermann, F. Wolf et enfin M. Diez dont les arguments philologiques ont confirmé l'opinion de ses prédécesseurs. Il est désormais acquis que ces divers poèmes, dans leur forme actuelle du moins, ne remontent pas au-delà du $\mathrm{XVI}^{\mathrm{e}}$ ou tout au plus de la fin du $\mathrm{XV}^{\mathrm{e}}$ siècle; aussi est-il superflu d'examiner les arguments par lesquels M. B[raga]. cherche à refuter Ribeiro» (Morel-Fatio 1873: 127).

84 «Les faits que M. Braga a réunis depuis, dans ses Epopeas da raça mosarabe (Porto, 1871), ch. IV, pour établir notamment l'authenticité de la chanson du Figueiral, prouvent uniquement $1^{\circ}$ que cette chanson était réellement populaire au XVI ${ }^{\mathrm{e}}$ siècle, $2^{\circ}$ que la légende sur laquelle elle s'appuie est beaucoup plus ancienne. C'est absolument le résultat auquel, Wolf est arrivé [cf. Wolf 1859: 693]» (ibid.).

85 Vasconcellos 1904: 267-69.

86 «M. Milá y Fontanals se esforzó, en su tiempo, con resultado negativo, por encontrar en Barcelona» este cancioneiro: cf. Anglés 1964: 149-50 n. 1.

87 «E a música que acompanhava a canção?» (Braga 1867: 248). 
Und man begreift nicht recht, wie und warum ein so unerschrockener Neuerer wie Th. Braga bis zur Stunde vorfährt, Lanzen zu brechen, um Unrettbarres zu retten.Scheinbar übt er ja strenge Kritik an Brito's, Andrada's, und Faria's Fabeleien; und leugnet das hohe Alter der Reliquien. Im Grunde aber macht er die Sache dadurch nur schlimmer, dass er sie aus dem 8. bis 11. jh. ins 12 . und 13., und später sogar ganz entschieden ins 14. und 15. verlegt! Mitten unter echten, uns wohl bekannten Kunstwerken, wirken die fratzenhaften Missgeburten poetischer Lügerschmiede nur noch abstossender als am leeren Eingange zur portug. Litteratur.

7. Eis aqui, finalmente, as conclusões de Teófilo Braga no que respeita à inteira questão. Como já foi dito, este pretendido Cancioneiro, além da Canção de Hermigues teria contido as três seguintes obras:

1) o fragmento do Poema (ou Lamentação) da Cava ${ }^{88}$ ou da Perda da Espanha: «São quatro oitavas em endechas, ou de gaita galega» ${ }^{89}$ que Faria y Sousa, aliás seguido por Sismondi (1817) e Bouterwek (1823), ${ }^{90}$ data do séc.IX, enquanto Pedro Ribeiro e Braga atribuem o fragmento ao século $\mathrm{XIII}^{91} \mathrm{e}$, respectivamente, ao fim do séc. $\mathrm{XV}$; este tipo de oitava «só apparece pela primeira vez usado em Hespanha por Affonso o Sábio, e em Portugal no século XV (...). $\mathrm{O}$ facto de andar no Cancioneiro do Conde de Marialva um Elogio da Língua portugueza, bem revela um intuito philológico da parte de quem simulou estas outavas» $;^{92}$

88 «Essas quatro Oitavas eram uma Lamentação da perda de Espanha, segundo o género de Lamentação, de que fala o Marquês de Santillana (...). O nome de Cava (do árabe Cabha, rameira), filha de D. Faldrina, irmã de D. Opas, muda-se no de Florinda na Verdadeira história de D. Rodrigo, por Miguel de Luna» (Braga 2009: 249-50). Pela etimologia proposta por Braga cf. Weston 1810: 144 cava, cabha 'Mulier má, an adultress'. O próprio diccionário Huaiss registra, como uso pejorativo e obsoleto, cava com o sentido de 'meretriz, prostituta'.

89 Braga 2009: 249. Se trata mais precisamente, como Braga tinha dito em seu Curso, de oitavas de arte mayor (abba,abba): cf. Vasconcellos 1897: 164 n. 2.

90 «These oldest relics of lyric composition in the Portuguese language seem to confirm the opinion, that the prevailing tone of romantic love, which caracterised the poetry of Spaniards and Portuguese (...), originated in Portugal. To paint romantic despair, and all the storms of passion, combined with the deepest resignation, existing not only in fancy, but in real life, appears to have formed the poetic costume of chivalry in Portugal even earlier than in Spain» (Bouterwek 1823: 7).

91 Jornal Amigos das Lettras cit., p. 136-37.

92 Braga 2009: 141. 
2) as duas Cartas com as Canções atribuídas à Egas Moniz Coelho: de Faria y Sousa, que lhes tinha retomado de Leitão de Andrada, elas passaram a Almeida Garrett, que delas fizera uma versão em língua portuguesa. Segundo Braga, Leitão de Andrade as atribuiu «gratuitamente a um cavaleiro da corte de D. Afonso Henriques», visto que nem o esquema métrico nem a língua são atestados nas obras dos trovadores: sem dúvida alguma, remontam ao séc.XV; quanto à Egas Moniz, nele tem-se que reconhecer uma personagem do fim do séc.XIV, quem traiu D. João I passando a defender a causa de Castilha; ${ }^{93}$

3) A Canção do Figueral ou Trovas dos Figueiredos ou de Goesto Ansur, publicada pela primeira vez por Brito: segundo Braga, «desprezadas as circunstâncias de que Frei Bernardo de Brito cercou este cantar velho, e o nome de Guesto Ansures, fica uma Canção bailada, ligada a um episódio da lenda de Tristão da novela do século XIII e XIV. E podemos mesmo considerá-la um Lai primitivo do perdido texto do Tristão português». ${ }^{94}$ Em seu Curso, Braga tinha igualmente afirmado que esta obra «é genuinamente popular», além do mais que «a forma métrica é semelhante à do romance de Ayras Nunes, do século XIV, o que mais confirma a sua authenticidade». ${ }^{95}$ Segundo Michaëlis (Grundriss, pp. 165-67), quem contudo, se guarda desta vez de subestimar os argumentos de Braga, esta obra é igualmente «eine Erfindung Brito's»; em todo caso, ela remonta ao séc.XV, ou mais precisamente ao séc.XVI.

O conjunto de objeções levantadas por Pedro Ribeiro, e sobretudo por Carolina Michaëlis, não ficaram sem eco, tanto é que apenas a Canção de Hermigues escapa finalmente, como foi visto, à revisão de Teófilo Braga, na qual ele fez prova de toda sua erudição.

93 Foi filho de Pedro Coelho e esposo de D. Maria Gonçalves Coutinho, filha de Gonçalo Vaz Coutinho; está aqui a origem dos Condes de Marialva.

94 Braga 2009: 250. «A lenda do Tributo das Donzelas, pago a Morhouet da Irlanda, foi transformada no Peito de Burdelo que recebia Mauregato, servindo o milagre da sua libertação para fundamento do Censo ou Votos de São Tiago» (ibid.). Cf. Vasconcellos 1897: 165 n. 6.

95 Braga 2009: 140-41: «A confusão das circumstâncias da lenda com o monumento poético fez com que João Pedro Ribeiro duvidasse da sua authenticidade, sem notar que as creações populares não se simulam, porque se ultrapassa sempre a sua ingenuidade». 
Michaëlis conclui que, segundo toda verossimilhança, o pretendido códex «era um opúscolo em prosa, em louvor da língua portuguesa, entremeado de documentos illustrativos, entre os quaes avultava uma das cinco relíquias prehistóricas! Nada mais é preciso para o caracterizar como producto do séc.XVII». ${ }^{96}$

8. A formação medieval de Brito enquanto historiador é bem conhecida, ${ }^{97}$ do mesmo modo seu «nacionalismo sebastianista». ${ }^{98}$ Em sua Crónica de Cister, de acordo com Camões e Antônio Vieira, Bernardo de Brito adiciona uma nova obra à lenda de Ourique, ${ }^{99}$ a qual «vê-se então ampliada com um pergaminho em latim forjado pelo monge de Cister, onde o primeiro monarca [Afonso Henriques] teria feito vários juramentos a Cristo. Este, por sua vez, teria dialogado com o rey», que o teria investido enquanto chefe de um povo eleito da missão de fundar um império, notadamente o Quinto Império. ${ }^{100}$

Quanto ao texto da Canção de Hermigues, o alemão Bellermann foi o primeiro a tentar interpretá-lo. Este cônego não se deixa levar pela pretendida antiguidade dessas relíquias: mesmo antes da sua tradução das Trovas dos Figuereidos, ele manifesta sérias dúvidas no que respeita à língua do texto. ${ }^{101}$ Passando à Canção de Hermigues, não escondeu sua perplexidade quanto à qualidade poética deste poema assim como à regularidade de seu esquema métrico; finalmente, julgou-o dificilmente compreensível em tudo o que concerne à lingua. ${ }^{102}$ Apesar de tudo, Bellermann não se recusa à prova de uma tradução:

96 Vasconcellos 1990: 269 n. 1. Cf. Moisés 2004a s.v. apócrifo.

97 Cf. Moisés 2004b: 199: «não raro as sua fontes são fictícias e forjados os documentos em que se apóia».

98 Cf. Soares 2007: 166 n. 519.

99 Ibid.: 90 n. 207.

100 Primeyra Parte da Chronica de Cister, cit., Livro III, cap. iii, Lisboa, 1602, f. 126-27: cf. Soares 2007: 44-45; 185.

101 «Die Sprache des Gedichtes ahmt allerdings das Galizische oder Altportugiesische des 13. Jahrhundert nach, doch ist auch manches ausschliesslich spätere, und manche nur spanische Sprachform beigemischt, wodurch das Lied jünger erscheint. Indessen wenn es auch erst dem 15. oder 16. Jahrhundert angehört, im Munde des Volkes

hat es gewiss gelebt, und ist kein Machwerk der Mönchs Brito» (Bellerman 1840: 2).

102 «Das Gedicht bietet sprachlich sehr grosse Schwierigkriten dar, und einzelne Worte sind ganz unerklärbar. Andere sprachliche Documente aus dem 12. Jahrhundert sind weit verständlicher. Dadurch wird die Composition des Liedes allerdings verdächtig. Übrigens 
Tinhera bos, nom tinhera bos,

Tal a tal ca monta.

Tinherades me, nom tinherades me, De la vinherades, de ca filharades,

$\mathrm{Ca}$ andabia tudo em soma.

Per mil goyvos trebelhando

Oy oy bos lombrego

Algorem se ca da folgança,

Asmey en, perque do terrenho

Nom a hi tal perchego.

Ouroana, Ouroana, oy tem per certo,

Que inha bida do biber
Gonçalo Hermiguez an Ouroana.

Schon hielt ich euch, dann hielt ich euch nicht, Hierhin und dorthin neigt sich der Kampf. Ihr hattet, and hattet wieder mich nicht, Von dort kamt ihr her, hier führtet ihr fort, Von allen Seiten wogte die Schaar.

Dort in tausend Scherzen spielend O musst' ich euch erschauen, Etwas liebliches gewahre ich dort, So dacht' ich bei mir, ein besser Jagen Giebt's nicht auf diesen Auen.

Ouroana, Ouroana, o glaub' es sicher, Nun erst gewann mein Leben

Se alvidrou per teu alvidro, per que em cabo Des Lebens Werth durch deine Wahl, nun endlich $\mathrm{O}$ que ey de la, chebome sem referta, Maa nom ha perque se ver.
Hält mich gefangen, was ich dort erkämpft.

Und nimmer kann es Schöneres geben.

Em comparação a este texto, Bellermann declara «noch zweifelhafte» a autenticidade dos dois poemas de Egas Moniz. É a partir da tradução dele que Almeida Garrett publicou sua versão da Canção de Hermigues. ${ }^{103}$ Não podemos deixar de reproduzir aqui a defesa que, de maneira tão brilhante e tão rica em humor, Garrett pronuncia antes de apresentar sua tradução:104

E, seja este um verdadeiro character de historia litteraria, ou seja apenas um mytho em que as gerações posteriores quizessem personalizar

fehlt es ihm nicht an Lebendigkeit und Innigkeit. Die Zeilen bewegen sich regellos ohne bestimmtes Versmaass, und nähern sich eher dem längeren, jambischen Rhythmus der provenzalischen Lieder, als dem kürzeren, trochäischen. Hie und da schimmert ein Reim und eine Assonanz durch. Bei der Unbestimmtheit vieler Ausdrücke ist ein Übersetzung sehr gewagt; sie möchte etwa wie die nebenstehende lauten, ohne dass das Einzelne verbürgt werden kann» (Bellerman 1840: 5).

103 Primeiramente na Revista Universal Lisbonense: Jornal de interesses physicos, moraes e intellectuaes (...). Redigido por José Maria da Silva Leal, Tomo V, Anno de 1845-1846 (entre 1842 e 1845 , a Revista tinha sido dirigida por A.F. de Castilho), dentro dum trabalho de síntese intitulado Da poesia popular em Portugal, que saiu neste tomo em três capítulos, sendo um de introdução (vejam-se pp. 439-441, 450-52, 460-62, 473-75, 483-85). Cf. ibid., Tomo VI, Anno de 1846-1847, pp. 99-102, onde Garrett publica e traduz as duas Cartas. A versão saiu logo em Escriptos diversos: veja-se Garrett 1877. Ver também Braga 1911: 197; Duarte 1978: 9, 14.

104 Citamos a partir de Garrett 1877: 193-94. 
o espirito cavalheiresco e poetico do tempo, o certo é que o seu nome e a sua imagem entraram no Walhala dos Lusitanos, d'onde os nao expulsarão nunca os severos requisitorios da. crítica moderna. Nenhum advogado do diabo faz j'agora revogar a sentença do consistorio popular que beatificou o nosso Traga-mouro, declarou genuínas as suas toscas e quasi inìntelligiveis trovas, e como reliquias preciosas as colocou, a par de sua imagem, no altar sagrado das mais queridas recordações nacionaes.

Seja Frei Bernardo de Brito convencido de impostor, Miguel Leitão d'Andrade de trapasseiro, Faria-e-Sousa de credulo ; fiquem Sarmiento e Andró desconceituados, e o nosso bom velho Antonio Ribeiro-dos-Sanctos havido por um pobre homem; tenham embora razão, contra todos estes que assim o creram, o terriveí João Pedro Ribeiro e o Dr. Beilerman que lho negam ; tudo isso pode ser, menos deixar-se a poesia portugueza desappossar-se de Gonsallo-Hermigues, da sua Oriana, e da sua canção ou cantar - embora mais gallego que outra coisa, é verdade; mas queremo'-lo e cremo'-lo assim: deixem-nos com a nossa fe do carvoeiro.

Veja-se a seguir a edição crítica da Canção de Hermigues por Almeida Garrett, ${ }^{105}$ assim como sua tradução em vulgar: ${ }^{106}$

Tinhera bos, non tinhera bos, ${ }^{107}$

Tal a tal ca assoma !108

Tinherades me, non tinherades me,

De la vinherades, de ca pilharades

Ca andabia ${ }^{109}$ tudo em soma.

Per mil goivos trebelbando, Oy, oy ! vos lombrego...
Ora vos tenho, ora não,

E um a um elles que chegam!

Já me apanhais e ja não...

D'aqui largam, e d'alli pegam,

Que anda tudo ao repellão.

Por mil golvos retoiçando

Ai, ai, que vos avistei!..

105 Ibid: 204-07.

106 As quais Garrett faz seguir a tradução de Bellermann. «Hätte Bouterwek nicht an die Ehrlichkeit Brito's geglaubt, und Bellermann nicht mit Hülfe der Novelle den Sinn der Vers-Zeilen enträtselt und sie frei und poetisch verdeutscht, so hätte Almeida-Garrett vielleicht seine Übertragung ins Neuportug. nichr geschrieben und das litterarische Unding begegnete uns nicht allerwärts. Schade, dass Diez, Wolf, Milá und Amador de los Rios es nicht kerniger abfertigten, vorsichtige Zweifel übrig lassen» (Vasconcellos 1897: 163).

107 A notar, entre as variantes consignadas por Garrett nas notas de rodapé, a curiosa leitura Tinherabos, non tinhe rabos que, conforme assinala Pulsoni 2006: 657 n. 39, já se encontra no texto reproduzido por Faria na Europa portuguesa. Esta leitura ainda se encontra em alguns manuais da época, por ex. Balbi 1822: 3; Denis 1826: 606.

108 Em lugar de ca monta (Brito, donde Bellermann e Faria y Sousa).

109 amabia em Brito e Faria y Sousa. 
Algorem se ca da folgança, Asmei eu, perque da terrenho Nom a hi tal perchego.

Ouroana, Ouroana, oy tem por certo Que inha bida, do biber

Se olvidrou per tu alvidro, per que em cabo $\mathrm{O}$ que ey de la chacone, ${ }^{110}$ sem referta, Mas nom a ${ }^{111}$ perque se ver.
Ja sei porque ando lidando, Que em taes terras, bem pensei, Melhor fructo não verei.

Oriana, Oriana, oh, tem por certo Que esta vida, do viver,

Toda em ti se olvidou n'aquelle appérto. E o que, em trôco eu vim a haver Não ha mais para se ver.

Ao fim do século, no Grundriss de Bartsch, Carolina Michaëlis repete uma última vez seu juízo sobre o texto deste poema : «formlose, unqualifizirbare Gedicht, innerlich und äusserlich gleich unwahr, in regellosen, reimlosen Zeilen, und mit Sprachformen, die nie und nirgend gelebt haben». ${ }^{112}$

Michaëlis qualifica de «Elfsilber» ou «Hendekasyllaben» os vv. 13, 14 e sem dúvida 11 (embora isto suponha no v.13 uma sinalefa depois de teu, e no v. 14 a eliminação do ei, que Michaëlis tacitamente sacrificou): «Auf diese drei Hendekasyllaben weisen denn auch alte wie neue Litteraturhistoriker, von Faria-e-Sousa bis Costa-e-Silva, als auf den wertvollsten Edelstein der Reliquie hin!». Em suas notas é que Michaëlis consigna a maioria de sua análise lingüística, da qual veja-se a seguir o essencial:

- as formas verbais tinhera e vinhera ${ }^{113}$ são «rein erfunden»;

- certas formas, dentre elas algorem lombrego, remetem ao dialeto da Beira do século XVI, que Brito, enquanto originário de Almeida, conhecia evidentemente muito bem. É no mesmo dialeto, cujo emprego literário é, aliás, bem conhecido desde Gil Vicente, que segundo Michaëlis, foram escritos tanto a trova dos Figuereidos quanto as duas Cartas d'Egas Moniz; ${ }^{114}$

110 chebone em Brito, donde Bellermann e Faria y Sousa.

111 não ha Brito; contudo, «em gallego e portuguez antigo escreveu-se sempre: nom $a »$ (Garrett).

112 Vasconcellos 1897: 162-63. O texto que ela comunica coincide com o de Brito com poucas exceções: andabia (em lugar de amabia), se (sem acento), asmei...per que, eu de (em lugar de eu ei de).

113 «Welche Diez (Hofpoesie, p.5) vergeblich zu erklären sucht»: a remissão é para Diez 1863: 5 .

114 «Besonders das ei für eu: mei für meu; boi für vou etc. Dass auch hier sprachliche Anachronismen nicht fehlen, hat schon Diez bemerkt (so die Personalflexionen ais, eis neben ades edes)» (Vasconcellos 1897: 164). 
- o betacismo (b em lugar de v) é «grobminhotisch»;

- nenhuma das formas utilizadas, nem mesmo goivos, pertence à língua dos trovadores;

- inha, aliás muito frequente em textos vernaculares, não é nada mais que uma má leitura do possessivo mha;

- chebone ,checona, chacona' segundo Braga, ${ }^{115}$ posto que checona seja a leitura de Gualter Antunes no ms. que ele teria tido em mãos. ${ }^{116}$ Mas o único que afirma ter visto este manuscrito é Ribeiro dos Santos (1745-1818), cuja leitura é chebome. ${ }^{117}$

Entre os poucos que, depois de Carolina Michaëlis, ainda tentaram interpretar estes versos, citamos aqui Antônio de la Iglesia, que retomou o texto e o acompanhou de um aparato de notas: ${ }^{118}$

2 'importa, vale, significa' I 3 'tomarais' I 5 ama 'amba'; bia 'via, camino'; soma 'suma'। 6 'flores campestres'; 'jugueteando, retozando' I 7 '(hoje) hoy'; lembr'ego 'recuerdo yo' I 8 'alguna cosa'; de cada f.; 'divertimiento'। 9 Asmei 'sospeché'। 10 Nom a hi tal per (a) chego: 'existe'; 'ahî'; 'fuerte arrimo'। 12 que i uha: 'ahî'; 'morar'। 13 'arbitró'; 'arbitrio'। 14 'tengo'; de la cha corre: 'de ella', '(que) te digo que'; 'reyerta, disputa' I 15 non ha 'tiene'; 'notarse'.

9. É a meados do séc.XIX, graças sobretudo à versão de Garrett, que a lenda de Gonçalo Hemigues goza mais e mais de celebridade na literatura portuguesa, sendo objeto, entre outros, de um romance histórico ${ }^{119}$ como

115 Que aliás «klaubte aus dem Gedicht di Übersetzung heraus, dass es ein Überrest einer zum Amadisromane gehörigen Gruppe von Chaconas de Oriana sei» (ibid.: 164). Cf. dic. Houaiss s.v. chacona ,dança lenta renascentista em compasso ternário'; primeira abonação: Melo 1665.

116 De fato, «die Schreibart checona stammt aus Costa-e-Silva's Ensaio, und ist eine der willkürlichen Änderungen, die dieser Literaturhistoriker sich gestattet hat».

117 Se bem que «herrliche und nicht umwissende», neste caso não é confiável, «weil er als überzeugter Keltomane, dem das moderne Portug. ein keltischer Dialekt war, für recht unverständliche alprotug. Monumente eine erklärliche Vorliebe hegte».

118 «En las transmisiones de esta cantiga, conocidamente hay error de copia, de alí nuestros entreparéntesis: las voces, empero, son todas del idioma galiciano», cf. De la Iglesia 1886: 44-46 (o autor era secretário do Consistorio dos Jogos Florais, celebrados pela primeira vez na Corunha em 1861, e verdadeiro promotor deles).

119 Cf. Chaves 1979, index anexado no apêndice. 
também de uma obra teatral. ${ }^{120}$ Como prova de seu renome é a alusão inserida por Camilo Castelo-Branco em sua obra Caração, cabeça e estômago (1862):

As vossas leis são assim... Uma mulher foge pela porta ou pela janela da casa paterna; manda adiante as trouxas do seu fato; amua-se contra a frieza do amante, se ele lhe faz reflexões para a conter em casa; vai ter, afinal, com ele, dizendo que já não pode esconder aos olhos da mãe o caro penhor que lhe palpita no seio. O pobre moço, obrigado pela honra, pela compaixão e pelo amor dela e do caro penhor, foge também aos pais e vai caminho de Santarém ou doutra parte. Vem depois atrás deles a lei, e diz: "Esta menina foi roubada aos pais; este homem é o raptor desta inocente, que vai violentada como a Fátima de Gonçalo-Hermigues, o Traga-Mouros." E depois...

A pesquisa de um pretendido laço com as tradições locais já era frequente; vejamos p.ex. esta passagem retirada dum manual de história da literatura portuguesa: ${ }^{121}$

A captiva ainda não ha muitos annos que a dançavam em Almada, em dia de San João. Vinham mouras agrilhoadas cercadas de guerreiros christãos, e entre todos se travavam vários passos dançantes, talvez em memoria da lenda de Gonçalo Hermingues, raptando n'esta mesma villa a moura Fátima, depois chamada Ouriana, quando convertida á fé de Christo, conforme a trova bem conhecida.

Hoje muitos guias, como também muitos sites na internet, relembram que a origem do topônimo da cidade de Ourem é a pesquisar no nome de Oureana. ${ }^{122} \mathrm{O}$ assunto está, aliás, na moda no que concerne à cultura galiciana, como nos mostra p.ex. um suplemento literário do jornal de La Coruña: ${ }^{123}$

O poema atribuído a Gonçalo Hermingues, suxeito sen verificación histórica, que se refire a unha Oureana (nome do que sairía o de Oriana no Amadís), modúlase nun trampitán dificilmente comprensíbel que delibera-

${ }^{120}$ Jacinto Heliodoro de Aguiar Loureiro (1806-?), Gonçalo Hermigues o TragaMouros, drama apresentado no Teatro Nacional em 1848; cf. Rebello 1980: 60.

121 Ferreira 1875: 117.

122 Cf. Coelho 1873: 480.

123 Méndez Ferrín 2009. 
damente se agalega convertindo as uves en bes. ${ }^{124} \mathrm{~A}$ un Egas Moniz Coelho, pretendido curmán de Egas Moniz, apónselle a autoría dunhas cartas ou cántigas de amor a Violante (nome imposíbel na Alta Idade Media). Para afectar antigüidade, o fabricante converte sistematicamente o diptongo eu en ei, como ocorre en algún dialecto. Curiosamente, a lingua destes versiños aparece relacionada coas actuais falas galegas do Val das Ellas, en Cáceres.

Fora de Portugal, o poeta inglês Robert Southey tinha escrito já no ano de 1801 uma balada intitulada Gonzalo Hermiguez, precedida de um prefácio tão belo quanto pertinente. ${ }^{125}$

10. Antes de concluir nosso trabalho, é preciso voltar à questão do uso que Faria y Sousa fez da Canção de Hermigues. Com efeito, ele reproduziu o texto para demonstrar que o emprego do decassílabo remonta às origens da poesia portuguesa. Mas, no texto transcrito por Faria y Sousa, teria realmente exemplos desse verso?

O problema já foi colocado pelo Padre Sarmiento ao examinar (pp. 223-24) as teorias enunciadas por Beuter e por Faria y Sousa:

Manuel Faria sólo copió del P. Brito desde Ouroana, Ouroana, \&c. de estas coplas; y sólo esto mismo copió Caramuel de Faria. Pero ninguno de ellos explicó el sentido de ellas (...). Y así Faria como Caramuel suponen que en estas coplas hay algunos versos Hendecasýlabos, y que su primer uso se debe a los Portugueses. Pondré las palabras latinas de Caramuel: «Ergo, nisi nova testimonia succurrant (dice en la página 105 de su Rhythmica, traduciendo a Faria), ${ }^{126}$ versus hi, quos Decasyllabos Rhythmici, \&

124 «Entenden vostedes algo? Eu non entendo nada. Non entendo e o disparate faime acordante dos versos de Xan da Cova, como escribía Curros. Ou sexa os versos que Don Juan de la Coba y Gómez escribía no Ourense decimonónico nun idioma inventado por el e por el mesmo denominado trampitán. Trampitán que estudou Filgueira Valverde, que emulou Torrente Ballester en La Saga/ Fuga de J.B. e que soaba deste xeito: "Don Viltrampo te ofrecía/los valles del verramoto/todas las viñas del tría/montes y vegas del troto...". Cando se puña clásico Xan da Cova resultaba estupendo no seu ousado extremismo: "Sus sos ao pusus fer per oselete, tretos ortase lareta zon”» (ibid).

125 «This story is related at length by Bernardo de Brito (...). The verses are said to be the oldest in the Portugueze language, and Brito says there were more of them, but he thought it sufficient to cite these for his purpose. If they had been correctly printed, it might have been difficult to make out their meaning, but from a text so corrupted it is impossible».

${ }^{126}$ A fonte de Caramuel foram os prólogos inseridos por Faria y Sousa em sua recolha de poemas Fuente de Aganipe, que o autor reutiliza no seu comentário as Rimas de Camões, assim como precisa Sarmiento 1775: 216-17. 
Grammatici Hendecasyllabos appellant, inventi sunt a Graecis; tran $<$ s $>$ lati ad Latinos: \& postea in rhythmos versi a Lusitanis, ante annos quingentos. Recepti ab Italis, \& Valentianis, ante quadringentos. Et ab Castellanis, ante trecentos. Et hoc respectu hujus anni millesimi sexcentesimi quinquagesimi. Unde colligitur, an Itali debeant vocari?».

Primeiramente, Sarmiento não crê que o texto seja tão antigo como Faria y Sousa o desejaria, «y en especial por haber notado que en materia de fechas, no es tan exacto este Autor como yo quisiera (...). Tampoco se halla en ellas [coplas] verso Hendecasýlabo perfecto; y si hay alguno, es fuera de intención; pues lo hay allí de todas medidas».

Sobre esse assunto, Sarmiento aproveita a ocasião para denunciar outra invenção feita por Aldrete, «sobre los libros de Granada, ${ }^{127}$ citando el verso Hendecasýlabo, o Sáphico de S. Cecilio, coetáneo de los Apóstoles, escrito en Castellano, v.g. La edad de la luz ya comenzada. Pero esto no sería averiguar la verdad, sino imaginar, o fingir pruebas, para mantener un preocupado dictamen». Em suma, Sarmiento representa em termos já atuais a ligação entre os decassílabos indígenas e os decassílabos que Navagero, e os italianos, importaram na Espanha do séc.XVI.

11. Em resumo. Na introdução do seu comentário às rimas camonianas, Faria y Sousa trata, entre outras coisas, da invenção do verso de onze sílabas correspondente ao hendecassílabo italiano. Naturalmente, ele fala em primeiro lugar dos poetas italianos, desde Federico II e a escola siciliana até ao stil nuovo, autores que ele lia na chamada Giuntina di rime antiche. Seu intuito, porém, é demonstrar que, na realidade, não foram os italianos os primeiros a utilizar o decassílabo. Por isso, aproveitando uma mistificação criada pelo cronista valenciano Beuter com base no conhecido Prohemio de Santillana, ele começa por afirmar que Petrarca, ao usar deste verso, se inspirou de Jordi de Sant Jordi.

Segundo Beuter, com efeito, Jordi esteve no auge «por los años 1250». Mesmo assim, os sicilianos continuariam a serem anteriores a ele. É a este ponto que Faria y Sousa apresenta a sua 'prova' decisiva, recorrendo a outra mistificação, o responsável da qual é o historiador Bernardo de Brito, seu contemporâneo. Trata-se da Canção de Gonçalo Hermigues, que Brito

127 Varias Antigüedades de España Africa y otras Provincias por el Doctor Bernardo Aldrete, Canónigo en la Santa Iglesia de Córdova. En Amberes, a costa de Juan Hanrey, 1614, p. 304. 
apresenta como sendo do ano de 1090. Este texto não passa de uma criação do próprio Brito, cuja intenção era prover a história das origens portuguesas com um novo mito, o do 'Traga-mouros'. Ora bem, segundo Faria y Sousa, esta 'canção' contém vários exemplos de decassílabos. Com isso, ele pode afirmar que o decassílabo nasceu em Portugal no séc.XI.

«A mitificação das origens primeiras de um povo, de uma nação ou mesmo de uma instituição resulta de um fito de engrandecimento e de legitimação da realidade fenoménica que se descreve num processo de construção da memória histórica. É especialmente a partir do séc.XVI que se desenvolve uma espécie de 'mercado europeu' dos imaginários nacionais ou das mitologias nacionais». ${ }^{128}$ Neste quadro, a exploração do tema das origens é orientado para fins políticos mais ou menos imediatos. ${ }^{129}$

$\mathrm{Na}$ época do Renascimento e da emergência dos modernos estados europeus, um tipo de humanista, que Eulàlia Duran chama de «historiadorpolític», desenvolveu um papel essencial na formação d'uma imagem nacional «construïda per un entramat ideològic fet a base de mites, de llegendes, de símbols». Este tipo de historiador «considera que la història ha d'estar al servei dels interessos de la monarquia com a representant de l'Estat o de la nació», assim «conrea un tipus d'història deliberadament didàctica, que pretén convèncer de la superioritat de la comunitat política al servei de la qual és escrita». Ora bem, são «les elucubracions sobre els orígens antics que que realment interessaren els humanistes i que constitueixen una part important i fins i tot predominant de totes les històries europees del Renaixement». ${ }^{130}$

Claro está que, tanto em Catalunha como em Portugal, as lendas essencialmente patrióticas estão em relação com a fondação do país depois da sua reconquesta contra os musulmães. «O historiador adapta a verdade histórica de forma a forjar uma espécie de história-parecer, uma história de combate, de tomada de posição projectada no terreno do passado (...). O seu ideal nobilitante do passado nacional funcionalizava a história na disputa ideológico-nacionalizante da primazia desses reinos em relação aos outros pares no macro-espaço continental europeu (...). É aqui que melhor se revela a artesania do historiador como um autêntico manipulador do passado».131

128 Franco s.d.: 56-72.

129 Bruhns/Burguère 2000.

130 Duran 1992: 9, 12.

131 Franco s.d.: 58. Como o artigo de Franco mostra, neste esforço de valorização das raízes primeiras de Portugal também participou o humanista Fernando Oliveira. 
$\mathrm{Na}$ época em que Faria y Sousa escrevia, em Portugal era ainda vivo o eco da presença política espanhola durante o reino de Felipe II. O país precisava de renovar seu prestigio cultural mediante a criação de novos mitos relativos às origens. Além disso, é preciso levarmos em conta as disputas, em particular entre catalãos e italianos, com respeito à primazia da língua. Este é o quadro em que temos que situar o Discurso de Faria y Sousa, com a sua tentativa de constituir uma cronologia fictícia no que respeita ao emprego do verso príncipe do petrarquismo europeu.

Estas, e outras, mistificações de Brito e Faria y Sousa suscitaram no séc.XIX, por um lado, um profundo interesse na literatura portuguesa (veja-se a tradução de Almeida Garrett), e por outro, uma longa e fervente polêmica entre Teófilo Braga e Carolina Michaëlis de Vasconcellos em volta da mitificação das origens ${ }^{132}$ bem como dos fundamentos da 'poesia popular', questões pelas quais tanto se apaixonaram o romantismo e o positivismo.

\section{Bibliografia}

AldeA, M.A./Pulsoni, C. (2006), "Per la storia del Cancioneiro da Ajuda: 1. Dalla sua compilazione a Ribeiro dos Santos”, La parola del testo 10: 59-117.

FERREIRA, Andrade J.M. (1875), Litteratura portugueza, Lisboa, Livraria editora de Mattos Moreira.

Anglés, H. (1964), La música de las Cantigas de Santa Maria del Rey Alfonso el Sabio, Barcelona, Deputación Provincial.

Aramon i Serra, R. (1997), "Problèmes d'histoire de la langue catalane", in Id., Estudis de llengua i literatura. Prefaci i edició a cura de J. Carbonell, Barcelona, Institut d'Estudis Catalans :505-50.

Armisén, A. (1982), Estudio sobre la lengua de Boscán: la edición de 1543, Universidad de Zaragoza - Libros Pórtico.

Askins, A. L-F. (1968), Cancioneiro de corte e de magnates. Ms. CXIV/2-2 da Biblioteca Pública e Arquivo Distrital de Évora, Berkeley \& L.A., University of California Press.

Avalle-Arce, J.B. (2001), Macías: Trovas, Amor y Muerte, in Ocaña, A. C. coord., Estudios galego-medievais, Santa Barbara (California): 177-88.

132 Sobre uma polêmica no mesmo âmbito, aliás mais conhecida, veja-se Buescu 1987; Ead. 1991. Foi Duarte Galvão que fixou, em 1505, a versão completa desta narrativa, reproduzida, mais tarde, pela chamada historiografia alcobacense: justamente Bernardo de Brito na sua Chronica de Cister (1602) e Fr. António Brandão na Terceira Parte da Monarquia Lusitana (Lisboa, INCM, 2008: fac-símil da ed. Pedro Craesbeck, 1632). Veja-se Silva 2001. 
BAlbi, A. (1822), Essai statistique sur le royaume de Portugal et d'Algarve, comparé aux autres états de l'Europe, et suivi d'un coup d'oeil sur l'état actuel des sciences, des lettres et des beaux-arts parmis les Portugais des deux hémisphères, Paris, Rey et Gravier.

Bellermann, Chr. Fr. (1840), Die alten Liederbücher der Portugiesischen oder Beiträge zur Geschichte der portugiesischen Poesie vom dreizehnten bis zum Anfang der sechzehten Jahrhundert, Berlin, Dümmler.

BEYRIE, J. (1994), Qu'est-ce qu'une littérature nationale? Écriture, identité, pouvoir en Espagne, Toulouse, Presses universitaires du Mirail.

Birch-Hirschfeld, A. ed. (1900), El Libro de los enxiemplos del Conde Lucanor e de Patronio, Text und Anmerkungen aus dem Nachlasse von H. Knust, Leipzig.

BlecuA, J. M. ed. (2003), El conde Lucanor, actualización de F. Gómez Redondo, Madrid, Castalia (1 ${ }^{\mathrm{a}}$ ed. 1969).

Bouterwek, F. (1823), History of Spanish and Portuguese Literature, tr. from the original German by Th. Ross, vol. 2, London, Boosey \& Sons.

Braga, T. (1911), Cancioneiro Popular Português, Coimbra (1 ${ }^{\mathrm{a}}$ ed. 1867).

Braga, T. (1870), História da literatura portuguesa, Porto Editora.

Braga, T. (1877), "O Cancioneiro portuguez da vaticana e suas relações com outros Cancioneiros dos séculos XIII e XIV”, Zeitschrift für romanische Philologie 1: 41-57.

Braga, T. (2009), Curso de História da Litteratura Portugueza Adaptado às Aulas de Instrucção Secundária, Lisboa, Nova Livraria Internacional Editora (1 ${ }^{\mathrm{a}}$ ed. 1885).

BRITO, B. de (1720), Chronica de Cister: onde se contam as cousas principaes desta Ordem, \& muitas antiguidades do reyno de Portugal: primeyra parte (...). Lisboa Occidental: na officina de Pascoal da Sylva.

Bruhns, H./Burguère, A. (2000) Historiographies et représentations nationales en Europe, Paris, École des Hautes-Études en Sciences Sociales (textos policopiados).

Buescu, A.I. (1987), O Milagre de Ourique e a História de Portugal de Alexandre Herculano. Uma polémica oitocentista, Lisboa, INIC.

BuEsCu (1991), "Um mito da origens da nacionalidade: O milagre de Ourique", in F. Bethencourt/D.R. Curto coords., A memória da nação, Lisboa, Sá da Costa :49-69.

CABré, L. (1998), "Notas sobre la memoria de Santillana y los poetas de la Corona de Aragón”, in A. Deyermond (ed.), Cancionero Studies in Honor of Ian Macpherson, London, Queen Mary and Westfield College :25-38. 
CAmpabadal i Bertran, M. (2004), El pensament i l'activitat literària del Setcents català, Barcelona, Edicions de la Universitat.

Carvalho, J. A. de Freitas (1988), Crónica do conde Don Pedro de Meneses, Programa Nacional de Edições Comemorativas dos Descobrimentos Portugueses, Porto (reimpr. Lisboa, Fundação C. Gulbenkian, 1997).

Castro, A. Pinto de (1988), “O Indice do cancioneiro do Padre Pedro Ribeiro, fac-simile e leitura diplomática”, Biblos 64: 135-70.

CERdÀ y Rico, F. ed. (1778), Gaspar Gil Polo, La Diana enamorada, Cinco libros que siguen los VII de Jorge de Montemayor, Madrid, Antonio de Sancha.

Chaves, Castelo Branco (1979), O romance histórico no romantismo português, Lisboa, ICALP (Biblioteca Breve, 45).

Chiner Gimeno, J.J. (1999), "Noves dades archivístiques sobre la mort de Jordi de Sant Jordi”, in S. Fortuño Llorens/T. Martínez Romero coords., Actes del VII Congrès de l'Associació Hispánica de Literatura Medieval, Castelló de la Plana, Publ. de la Universitat Jaume I, t. 2 :67-70.

Clavería, C. ed. (1999), Juan Boscán, Obra completa, Madrid, Cátedra.

Coelho, E. (1873), Passeios na província, Lisboa, Typographia Universal.

ColÁn, M. (2007-2008), “Breves reflexiones sobre ‘Amadís de Gaula’ y la literatura caballeresca”, Estudios Románicos 16-17 :779-89.

DE LA IGLesia, A. (1886), El Idioma gallego, su antigüedad y vida, La Coruña, Impr. de La Voz de Galicia, 3 vols.

Denis, F. (1826), Résumé de l'Histoire littéraire du Portugal, suivi du Résumé de l'Histoire littéraire du Brésil, Paris, Lecointe et Durey.

DiAs, A.F. ed. (1990), Cancioneiro Geral de Garcia de Resende, Lisboa, IN-CM, 1990, 6 vols.

DIEZ, Fr. (1863), Über die erste portugiesische Kunst und Hofpoesie, Bonn, Weber.

Dotтı, U. ed. (1991), Francesco Petrarca, Le Familiari, Libro primo, Roma, Archivio G. Izzi.

Duarte, M.A. Zaluar (1978), O cancioneiro popular em Portugal, Lisboa, ICALP (Biblioteca Breve, 23).

DURAN i Grau, E. (1991), "Defensa de la pròpia tradició davant d'Itàlia al segle XVI", in A. Ferrando/A.G. Hauf coords., Miscel-lània Joan Fuster. Estudis de llengua i literatura, Barcelona, Publicacions de l'Abadia de Montserrat, t. $3: 241-65$.

Duran i Grau, E. (1992), "Lliçó inaugural del curs: Sobre la mitificació dels orígens històrics nacionals catalans", Anuari de l'Institut d'Estudis Catalans, 1991-1992, 1992 :9-20. 
EARLE T. F. (1990), Musa renascida: a poesia de António Ferreira, tr. de l'anglais [1988] de Maria Clarinda Moreira em coll. com o autor, Lisboa, Caminho.

EARLE, T.F. ed. (2000), António Ferreira, Poemas Lusitanos, Lisboa, Fundação C. Gulbenkian.

FERnÁndez SÁnchez, M.M./Sabio Pinilla, J.A. (1999), “Tradición clásica y reflexiones sobre la traducción en la corte de Aviz", Hieronymus 8: 61-72.

FRANCO, J.E. (s.d.), Mitificação das origens da nacionalidade: Portugal no âmbito da afirmação das nacionalidades europeias na modernidade, in P. Calafate, J.E. Franco e B.E. Cieszińska coords., Mitos da construção da identidade nacional e emocional: uma perspectiva comparativa luso-polaca, Lisboa :56-72 (na rede).

Gargano, A. (1988), Fonti miti topoi, Napoli, Liguori.

Garrett, Almeida (J.B. da Silva Leitão) (1877), “O Traga-Mouro”, em C. Guimaraens ed., Escriptos diversos (Obras do Visconde de Almeida-Garrett, 24), Lisboa, Imprensa Nacional :191-207.

Gómez Moreno, Á. (1983), “Tradición manuscrita y ediciones del Proemio de Santillana", Dicenda 2: 77-110.

Gómez Moreno, Á. (1990), El 'Prohemio e Carta' del Marqués de Santillana y la teoría literária del siglo XV, Barcelona, Promociones y Publicaciones Universitarias.

KING, Larry ed. (1978), Chronica do Conde D. Pedro de Meneses de Gomes Eanes de Zurara, Universidade Nova de Lisboa.

Massó Torrents, J. ed. (1902), Jordi de Sant Jordi, Obres poètiques, Barcelona, L'Avenç.

MÉndeZ FERrín, X.L. (2009), “As orixes fabulosas da literatura portuguesa”, em Saberes, Suplementos de La Opinión A Coruña, 21 novembre.

MenÉndez y Pelayo, M. (1908), Antología de poetas líricos castellanos, vol. 13, Madrid, Librería Sucesores de Hernando.

Morel-Fatio, A. (1873), Romania 2:127 [rec. de várias obras de T. Braga]

MoisÉs, M. (2004a), A literatura portuguesa através dos textos, São Paulo, Cultrix.

MoIsÉs, M. (2004b), Dicionário de termos literários, São Paulo, Cultrix.

Muñoz y GarnicA, M. ed. (1957), Gonzalo Argote de Molina, Nobleza del Andalucía: libros I y II, Jaén, Instituto de Estudios Ginnenses (repr. da $1^{\text {a }}$ ed. Jaén, López Vizcaíno, 1886).

Navarrete, I. (1997), Los huérfanos de Petrarca, Poesía y teoría en la España renacentista, Madrid, Gredos. 
Pepe Sarno, I. ed. (2001), Fernando de Herrera, Anotaciones a la poesía de Garcilaso, Madrid, Cátedra.

Place, E. B. ed. (1959-1969), Amadís de Gaula, Madrid, Conselho Superior de Investigações Científicas, 4 vols.

Pulsoni, C. (2006), "Il Cancioneiro da Ajuda e dintorni”, in S. Meritxell/H. Roig coords., Trobadors a la península ibérica: Homenatge al Dr. Martí de Riquer, Barcelona, Publicacions de l'Abadia de Montserrat: 285-310.

Pulsoni, C. (2009), "Di un' antica lirica pre-trobadorica in lingua lusitana: Letteratura, falsi e politica nel Portogallo del '600”, in F. Brugnolo/F. Gambino coords., La lirica romanza del Medioevo: Storia, tradizioni, interpretazioni, Atti del VI Convegno triennale della S.I.F.R., Padova, Unipress: 625-72.

REBELLO, L.F. (1980), O teatro romântico (1838-1869), Lisboa, ICALP (Biblioteca Breve, 51).

Ribeiro, J.P. (1810), Dissertações Chronologicas e Criticas sobre a Historia e Jurisprudencia Ecclesiastica e Civil de Portugal publicadas por ordem da Academia R. das Sciencias de Lisboa, na Typografia da mesma Academia.

RiQuer, M. de ed. (1951), Andreu Febrer, Poesies, Barcelona, Barcino.

RiQuer, M./BADIA, L. eds. (1984), Les poesies de Jordi de Sant Jordi, València, Tres i Quatre.

RoIG, A. (1978), "Deux sonnets d'António Ferreira dans la Langue des Troubadours", in Mélanges de philologie romane offerts à Charles Camproux, 2 vols., Montpellier, C.E.O., 1978, I :195-216.

Salas y Tovar, José Pellicer de ed. (1971), Lecciones solemnes de las obras de Don Luis de Góngora y Argote, Hildesheim/N.Y., G. Olms (repr. fac-similada da ed. publicada «En Madrid. En la Imprenta del Reino. A costa de Pedro Coello, Mercader de Libros. 1630»)

SÁnCHEZ, T.A. (1864), Poetas castellanos anteriores al siglo XV, Colección hecha por D. T.A. Sánchez, continuada por el excelentíssimo señor D. P.J. Pidal, considerablement aumentada (...) por D. Fl. Janer, Madrid, M. Rivadaneyra.

SÁnChEZ LASMARÍAs, E. (2008), "Edición del 'Libro del infante D. Pedro de Portugal' de Gómez de Santisteban”, Memorabilia 11: 1-30.

SARAiva, A. J./LóPES, O. (1989), História de la literatura portuguesa, Porto Editora. SARmiento, M. (1775), Memorias para la Historia de la Poesia, y Poetas Españoles. Dadas a luz por el Monasterio de S. Martín de Madrid. Por D. Joachín Ibarra Impresor de Cámara de S.M., Madrid (Obras posthumas, t. I) :§ 482-516= p.210-27 (De los versos Hendecasýlabos, o de Sonetos). 
SILVA, A. Malheiro da (2001), "Para uma abordagem metanalítica da Restauração", in L.A. de Oliveira Ramos (et alii), Estudos em homenagem a João Francisco Marques, Universidade do Porto, Faculdade de Letras, t. II :387-418.

Simon DE Sismondi, J-Ch. L. (1817), Littérature du Midi de l'Europe, Paris, 4 vols.

SoARES, M. L. de Castro (2007), Profetismo e Espiritualidade de Camões a Pascoaes, Coimbra, Imprensa da Universidade.

SORIANO FUERTES, M. (1855-1859), Historia de la Música Española desde la venida de los Fenicios hasta el año de 1850, Madrid y Barcelona, Imp. de Narciso Ramírez, t. I.

SpagGiari, B. (1992), O Renascimento italiano e a poesia lírica de Camões, Rio de Janeiro.

TiscorniA, E.F. ed. (1995), Gonzalo Argote de Molina, El «Discurso sobre la Poesía Castellana». Prólogo de J. Romera, Madrid, Visor.

VAlsalobre, Pep (2007), "Història d'una superxeria: el cas Jordi de Sant Jordi", in El (re)descubriment de l'edat moderna, Estudis en homenatge a Eulàlia Duran, Barcelona, Publ. de l'Abadia Montserrat/Universitat de Barcelona: 295-335 (citamos a partir do texto disponível on-line)

VAsconcellos, C. Michaëlis de (1897), “Apokrypha”, in G. Gröber (Hrsg.), Grundriss der romanischen Philologie, II. Band, 2. Abteilung, III. Abschnitt, B. (Die Litteraturen der romanischen Völker), 4. Geschichte der portugiesischen Litteratur von C.M. de Vasconcellos und T. Braga, Strassburg, Karl J. Trübner: 129-382.

Vasconcellos, C. Michaëlis de (1904), Glossário do Cancioneiro da Ajuda, vol. II. Reimpr. da ed. de Halle (1904), acrescentada de um prefácio de Ivo Castro e do glossário das cantigas (Revista Lusitana, XXIII), Lisboa, IN-CM, 1990.

Villalmanzo Cameno, J. (1993), "Data i lloc de la mort de Jordi de Sant Jordi”, Caplletra 15: 63-73.

Weston, S. (1810), Remains of Arabic in the Spanish and Portuguese Languages, London, Payne, Pall Mall/Clark, New Bond Street.

Wolf, Fr. (1859), Studien zur Geschichte der spanischen und portugiesischen Nationalliteratur, Berlin, A. Asher.

Zurara, Gomes Eanes de (1792), Chronica do Conde D. Pedro de Meneses, Lisboa, Colecção de Livros Inéditos da História Portuguesa, 2.

Zurara, Gomes Eanes de (1988), Chronica do Conde D. Pedro de Meneses, repr. fac-similada apresentada por J.A. de Freitas Carvalho, Porto, Programa Nacional de Edições Comemorativas dos Descobrimentos Portugueses (reimpr. Lisboa, Fundação C. Gulbenkian, 1997). 